\title{
Phase IV Testing of Monosodium Titanate Adsorption with Radioactive Waste
}

by

D. T. Hobbs

Westinghouse Savannah River Company

Savannah River Site

Aiken, South Carolina 29808

R. L. Pulmano

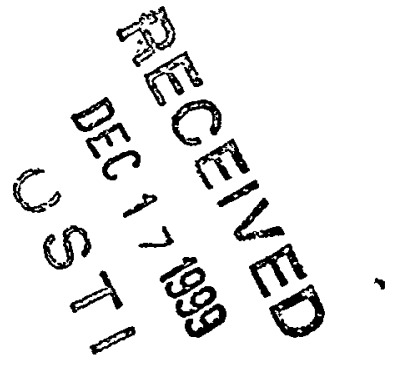

This paper was prepared in connection with work done under the above contract number with the U.S. Department of Energy. By acceptance of this paper, the publisher and/or recipient acknowledges the U. S. Government's right to retain a nonexclusive, royalty-free license in and to any copyright covering this paper, along with the right to reproduce and to authorize others to reproduce all or part of the copyrighted paper. 


\section{DISCLAIMER}

This report was prepared as an account of work sponsored by an agency of the United States Government. Neither the United States Government nor any agency thereof, nor any of their employees, makes any warranty, express or implied, or assumes any legal liability or responsibility for the accuracy, completeness, or usefulness of any information, apparatus, product or process disclosed, or represents that its use would not infringe privately owned rights. Reference herein to any specific commercial product, process or service by trade name, trademark, manufacturer, or otherwise does not necessarily constitute or imply its endorsement, recommendation, or favoring by the United States Government or any agency thereof. The views and opinions of authors expressed herein do not necessarily state or reflect those of the United States Government or any agency thereof.

This report has been reproduced directly from the best available copy.

Available for sale to the public, in paper, from: U.S. Department of Commerce, National Technical Information Service, 5285 Port Royal Road, Springfield, VA 22161, phone: (800) 553-6847, fax: (703) 605-6900

email: orders@ntis.fedworld.gov

online ordering: http://www.ntis.gov/ordering.htm

Available electronically at http://www.doe.gov/bridge

Available for a processing fee to U.S. Department of Energy and its contractors, in paper, from: U.S. Department of Energy, Office of Scientific and Technical Information, P.O. Box 62, Oak Ridge, TN 37831-0062, phone: (865)576-8401, fax: (865)576-5728

email : reports@adonis.osti.gov 


\section{DISCLAIMER}

Portions of this document may be illegible in electronic image products. Images are produced from the best available original document. 


\section{Phase IV Testing of Monosodium Titanate Adsorption With Radioactive Waste}
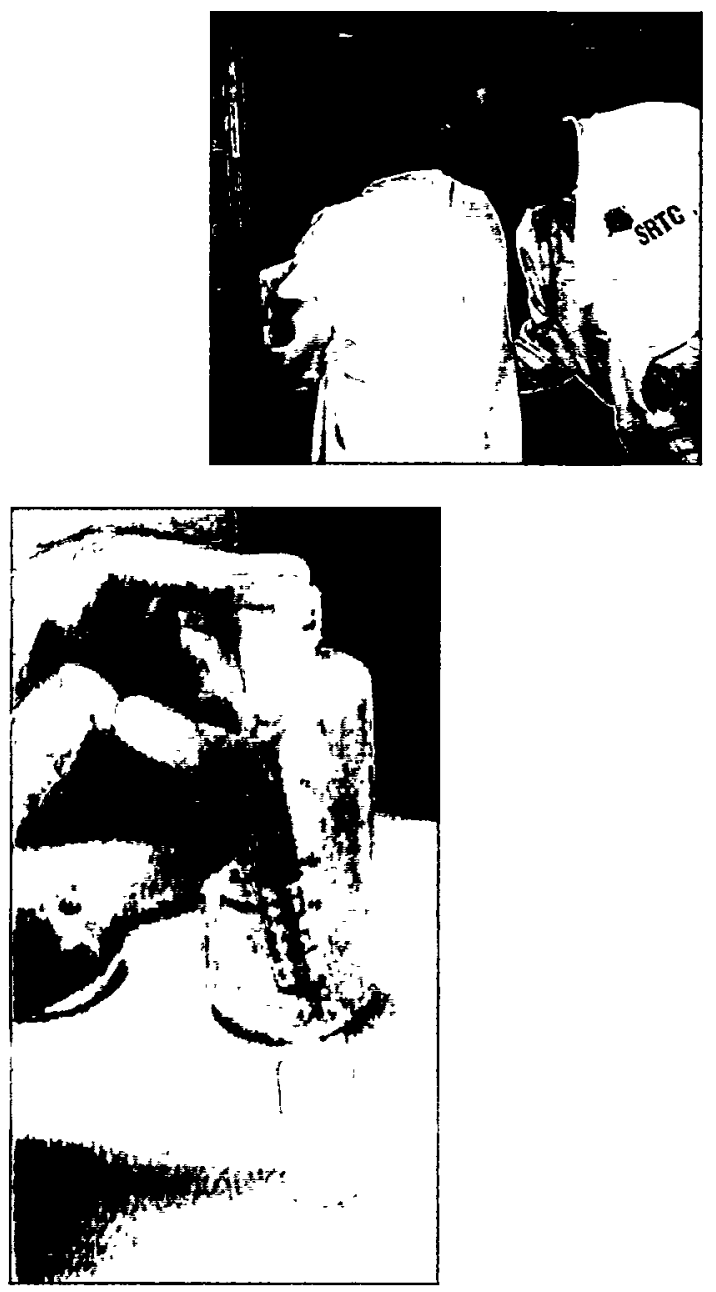

D. T. Hobbs, 773-A

R. L. Pulmano, 773-24A

Publication Date: September 3, 1999

Westinghouse Savannah River Company

Savannah River Technology Center Aiken, SC 29808
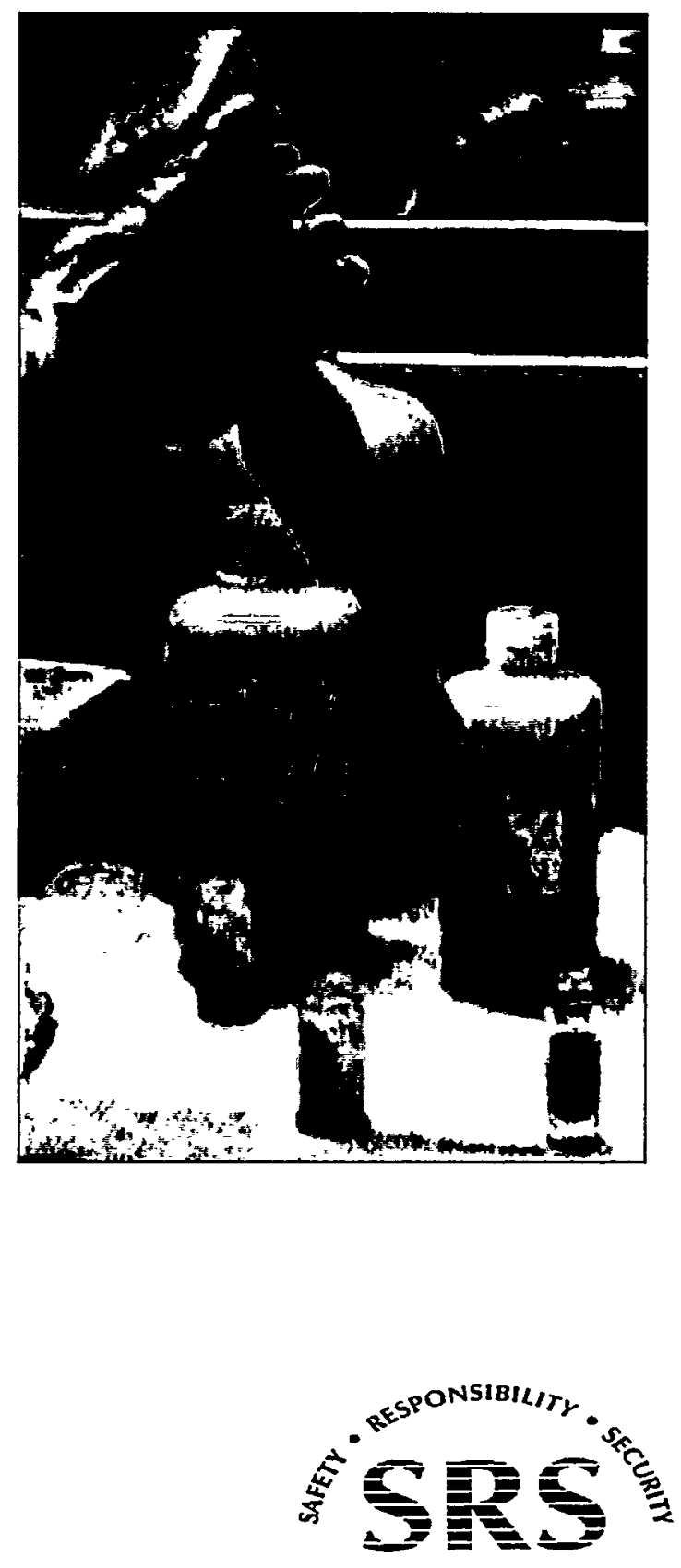

SAVANNAH RIVER SITE 
WSRC-TR-99-00286

page 2 of 29

Revision 0

Authors

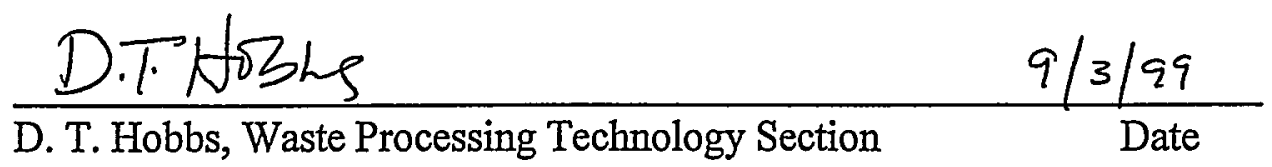

$\frac{\text { D.T. Jobs for R.L.Pulmeno }}{\text { R. L. Pulmano, Waste Processing Technology Section }}$

Design Check
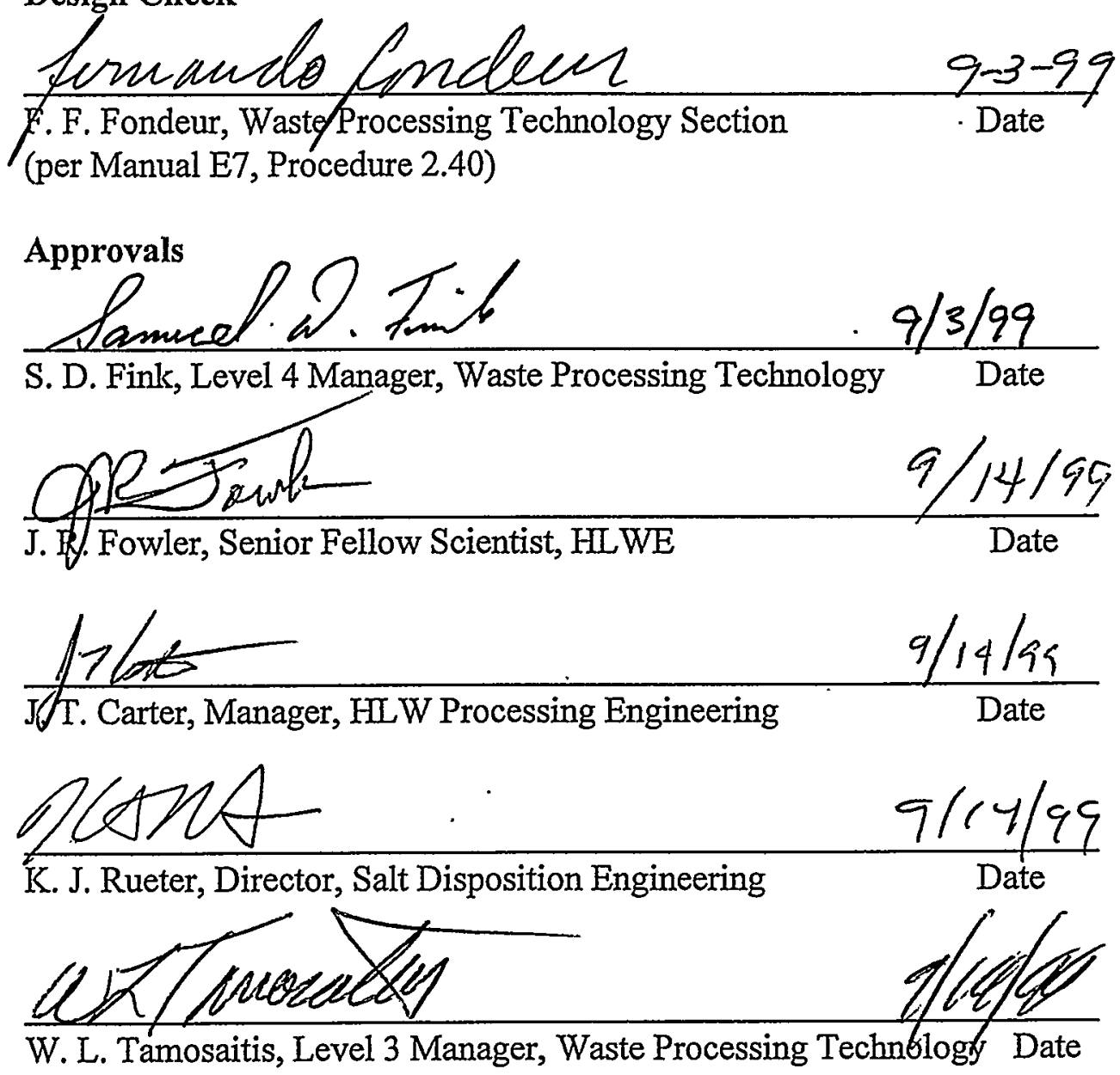


\section{Summary}

Testing examined the extent and rate of strontium, plutonium, uranium and neptunium removal from radioactive waste solutions at $4.5 \mathrm{M}$ and $7.5 \mathrm{M}$ in Na concentration by adsorption onto monosodium titanate (MST) at $0.2 \mathrm{~g} / \mathrm{L}$. Results indicate that the extents and rates of strontium, plutonium and neptunium removal in radioactive waste solutions agree well with those previously measured using simulated waste solutions. Uranium removal in the $7.5 \mathrm{M} \mathrm{Na}$ radioactive waste solution proved similar to that observed with simulated waste solutions. Uranium removal in the $4.5 \mathrm{M} \mathrm{Na}$ radioactive waste solution proved lower than expected from previous simulant tests. We conclude that MST adsorption data obtained from simulated waste solutions provide reliable predictions for use in facility design and flowsheet modeling studies in the Salt Disposition Alternatives program.

\section{Introduction}

The Salt Disposition Systems Engineering Team identified the adsorption kinetics of actinides and strontium onto monosodium titanate (MST) as a technical risk in several of the processing alternatives selected for additional evaluation in Phase III of their effort. The Flow Sheet Team requested that the Savannah River Technology Center (SRTC) examine the adsorption kinetics of MST for several process alternatives [1].

Previously, Hobbs and Walker studied the adsorption of strontium, plutonium and uranium onto MST in alkaline solutions [2]. Results of these tests indicated that MST would remove strontium, uranium and plutonium from simulated In-Tank Precipitation (ITP) waste solutions. Hobbs and Fleischman followed with statistically designed experiments to examine temperature and solution chemical composition [3]. Again, the results clearly indicated that MST would sufficiently remove strontium, uranium and plutonium.

Phase III testing identified significant parameters affecting sorption including ionic strength of the solution, temperature, initial sorbate concentration and MST concentration [4]. Mixing and the presence of sludge solids exhibited minor effects. Sodium tetraphenylborate (NaTPB) did not significantly affect the extent and rate of removal. Removal rates determined at a low MST concentration allowed initial sizing of reactors in various salt alternative flowsheets. Analysis of the results indicated the need to perform additional kinetic testing with simulants at lower neptunium concentrations and with radioactive waste solutions to confirm the results with simulated waste solutions.

Phase IV simulant testing by Hobbs and Pulmano used a simulated waste solution, $4.5 \mathrm{M}$ in sodium concentration, to measure the extent and.rate of strontium, plutonium, neptunium, and uranium removal at $25^{\circ} \mathrm{C}$ in the presence of 0.2 and $0.4 \mathrm{~g} / \mathrm{L}$ MST [5]. Results indicated successful decontamination at $0.4 \mathrm{~g} / \mathrm{L}$ MST. At $0.2 \mathrm{~g} / \mathrm{L}$ MST, neptunium removal did not achieve the Z-Area limit for feed solution due to the large concentration of uranium in the simulant. Removal rates determined at both MST concentrations provided additional data for sizing continuously stirred tank reactors. 
As defined in the technical task request [6], this study used Savannah River Site (SRS) tank waste to confirm that the extent and rate of removal from radioactive waste solutions agrees with that from simulated waste solutions.

\section{Experimental}

Preparation of Waste Solutions

The radioactive waste used in this experiment consisted of a composite of archived supernate and saltcake samples taken from more than twenty SRS tanks. Researchers combined and thoroughly mixed the samples producing $4.7 \mathrm{~L}$ of material. The composite material contained a small amount of dark-colored solids. Researchers did not characterize the quantity or composition of the undissolved solids.

Researchers characterized the liquid portion of the tank composite after filtering a portion of composite material through a $0.45-\mu \mathrm{m}$ pore size membrane filter (cellulose nitrate) and collecting the filtrate. Table I provides selected chemical, radiochemical and physical property results of the filtrate. Appendix 1 provides a more complete chemical and radiochemical composition of the filtered tank composite.

\section{Table I. Selected Analytical Results of the Filtered Tank Composite Solution}

$\begin{array}{lll}\text { Analyte } & \text { Value } & \text { Units } \\ \text { Density } & 1.362 & \mathrm{~g} / \mathrm{mL} \\ \text { Sodium } & 9.66 \pm 0.18 & \mathrm{M} \\ \text { Potassium } & 7.08 \pm 0.47 \times 10^{-2} & \mathrm{M} \\ \text { Tetraphenylborate Demand } & 6.48 \pm 0.085 \times 10^{-3} & \mathrm{M} \\ { }^{137} \mathrm{Cs} & 1.38 \pm 0.02 & \mathrm{Ci} / \mathrm{L} \\ { }^{90} \mathrm{Sr} & 2.10 \pm 0.07 \times 10^{-4} & \mathrm{Ci} / \mathrm{L} \\ { }^{239240} \mathrm{Pu} & \mathrm{bdl} & \end{array}$

$$
\text { bdl }=\text { below detection limit }
$$

Researchers treated the waste solution with sodium tetraphenylborate to remove radioactive cesium. Removal of the radioactive cesium allowed removal of the waste material from the Shielded Cells and thus performance of the adsorption tests in a laboratory radiohood. Removal of the radioactive cesium also increased the lower detection limit for other radioisotopes (e.g., ${ }^{90} \mathrm{Sr},{ }^{239240} \mathrm{Pu}$ and ${ }^{238} \mathrm{Pu}$ ) present in the waste. The task plan required conducting tests with waste solution at two sodium $(\mathrm{Na})$ concentrations, 4.5 and $7.5 \mathrm{M}$ [7]. A detailed description of the activities employed to prepare the two waste solutions for the MST adsorption tests follows.

Researchers diluted a portion $(0.808 \mathrm{~L})$ of the tank composite material to about $8.0 \mathrm{M}$ in $\mathrm{Na}$ and added $152.0 \mathrm{~g}(146.9 \mathrm{~mL})$ of a $0.55 \mathrm{M}$ sodium tetraphenylborate solution (NaTPB) prepared using Aldrich (Lot \#15123AS) reagent grade chemical. A second addition consisted of $36.549 \mathrm{~g}$ of a $0.55 \mathrm{M}$ NaTPB solution 17 days later. After another 10 days, researchers filtered the entire mixture through a $0.45-\mu \mathrm{m}$ pore size membrane filter (cellulose nitrate). We then placed the filtrate into a clean polyethylene $(\mathrm{PE})$ bottle and added another $48.233 \mathrm{~g}$ of a $0.55 \mathrm{M}$ NaTPB solution. After mixing for an additional 10 
days, personnel filtered the mixture through a $0.45-\mu \mathrm{m}$ pore size membrane filter (cellulose nitrate). We placed the filtrate in a clean bottle, removed from the Shielded Cells and transferred to laboratory module B-126/130 in SRTC.

Chemical analysis indicated the sodium ion concentration in the treated filtrate at $6.93 \mathrm{M}$, below the target of $7.5 \mathrm{M}$. Thus, researchers heated the solution slowly to $85^{\circ} \mathrm{C}$ and concentrated the solution by evaporation. Researchers did not detect the formation of : solids during evaporation. After evaporation, chemical analysis indicated a sodium ion concentration in the treated filtrate of $7.76 \mathrm{M}$.

Researchers added $50 \mu \mathrm{L}$ of ${ }^{85} \mathrm{Sr}$ tracer (NEN-087,) and $25.006 \mathrm{~g}$ of deionized, distilled (DDI) water to the treated tank composite filtrate and mixed 3 hours at ambient laboratory temperature. Researchers then added $100 \mu \mathrm{L}$ of a $0.671 \mathrm{mg} / \mathrm{L}{ }^{237} \mathrm{~Np}$ in $0.1 \mathrm{M}$ nitric acid solution (prepared from SNM 82014652,) and $25 \mu \mathrm{L}$ of ${ }^{85} \mathrm{Sr}$ tracer. After stirring overnight, we filtered the material through a $0.45-\mu \mathrm{m}$ filter and the filtrate placed in a clean PE bottle labeled as Multi-Tank Composite, $7.5 \mathrm{M} \mathrm{Na}^{+}$. Personnel then diluted a portion $(398.4 \mathrm{~g})$ of the composite solution with DDI water in a 500-mL volumetric flask to provide $600.3 \mathrm{~g}$ of the waste solution at a sodium concentration of $4.5 \mathrm{M}$. We stirred the diluted solution for 2 days at ambient laboratory temperature, filtered through a 0.45 $\mu \mathrm{m}$ pore size membrane filter (cellulose nitrate) and placed the filtrate in a clean PE bottle labeled as Multi-Tank Composite, $4.5 \mathrm{M} \mathrm{Na}^{+}$.

\section{Adsorption Tests}

Researchers placed $120 \mathrm{~mL}$ of solution into each of six labeled PE bottles (duplicates with $0.2 \mathrm{~g} / \mathrm{L}$ MST and one control with no added MST for each sodium concentration). The MST used in these tests was received from Optima Chemical Company (Lot \#33180) and is the same material previously used in the Phase III and Phase IV simulant testing [4,5]. Researchers randomly placed the bottles in a Lab Line shaking waterbath (Cole-Parmer Catalog \#E-01290-20) set to maintain a temperature of $25^{\circ} \mathrm{C}$. Personnel kept the level of the water at or above the liquid level in the sample bottles. A thermistor thermometer (Omega ${ }^{\oplus} \mathrm{Model} \#$ 5831) with probes (Omega ${ }^{\circledR} \mathrm{Model}$ \#OL-703) was used to measure waterbath temperatures. After incubating overnight, testing began with an initial sampling of the control bottles, and the addition of the appropriate quantity of MST to provide a MST concentration of $0.2 \mathrm{~g} / \mathrm{L}$. Each bottle was sampled in random order at $0.25,0.5$, $0.75,1.0,1.5,2,4,8,24,96$, and 168 hours after the addition of MST.

Figure 1 shows a graph of the recorded waterbath temperatures. Over the test duration, the temperature averaged $25.57^{\circ} \mathrm{C}$ with a standard deviation of $0.18^{\circ} \mathrm{C}$ including the incubation period of 17.8 hours prior to the addition of the MST. 


\title{
Figure 1. Waterbath Temperatures during Radioactive Waste Testing
}

\author{
Experimental Temperatures
}

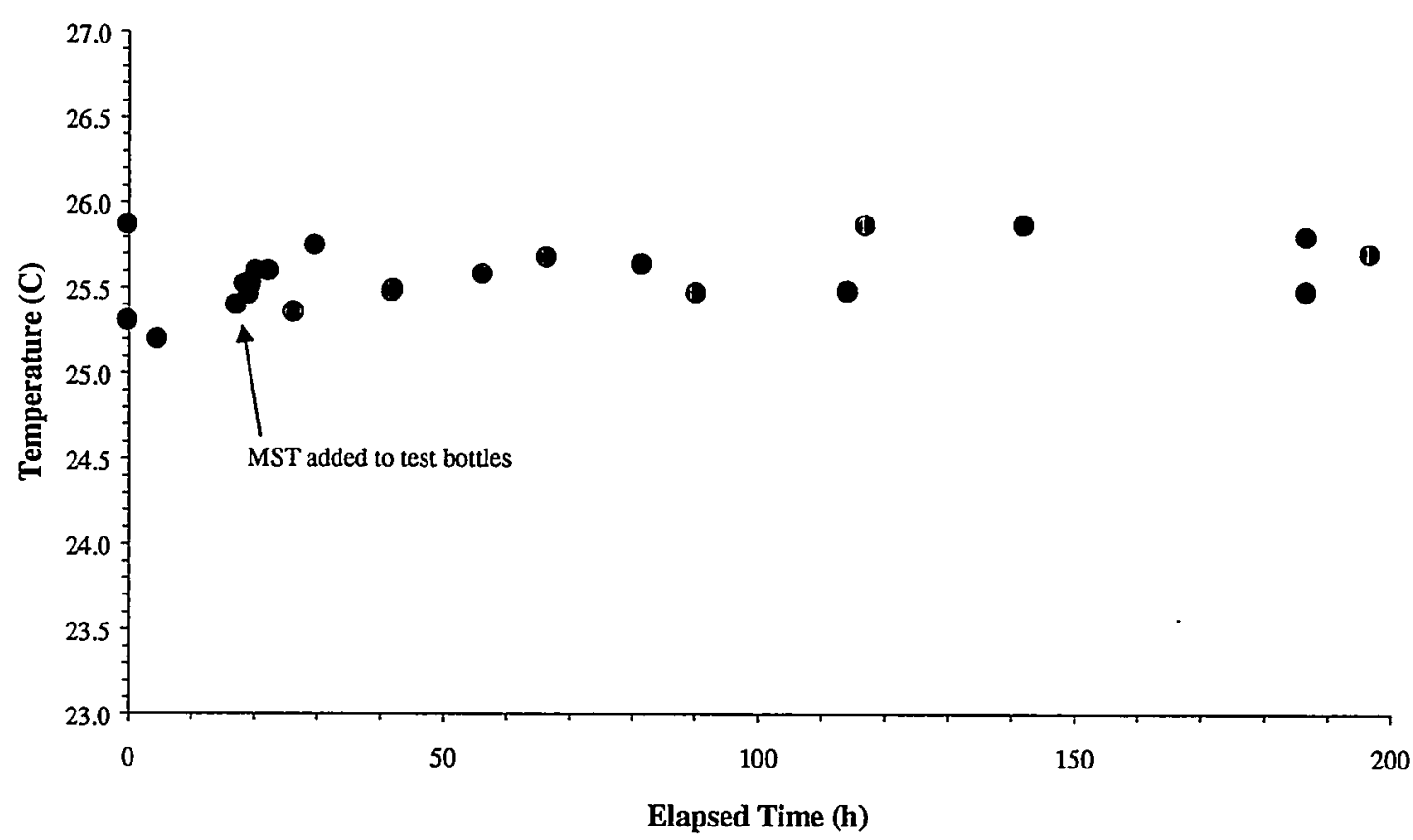

The sampling method consisted of removing a test bottle from the waterbath, briskly shaking for about 30 seconds to provide a homogeneous suspension, and pulling approximately $5-6 \mathrm{~mL}$ of the suspension into a disposable plastic syringe. The researcher then inserted a $0.45 \mu \mathrm{m}$ disk filter (nylon membrane) onto the syringe, collected about 5 $\mathrm{mL}$ of filtrate into a clean PE sample bottle and slowly pipetted $4 \mathrm{~mL}$ of the resulting filtrate into a glass vial containing $4 \mathrm{~mL}$ of $5 \mathrm{M}$ nitric acid.

Upon mixing of the sample and the nitric acid, an immediate reaction ensued resulting in the release of a brown colored gas and the formation of a white precipitate. Photographs below show the sampling events. The brown gas released immediately upon contact with the acid is $\mathrm{NO}_{\mathrm{x}}$, produced by the decomposition of nitrite. The white solids are aluminum hydroxide. Upon standing in an excess of nitric acid, the precipitated aluminum hydroxide dissolves. The bright yellow color disappears leaving a colorless solution. The observed color change is consistent with decomposition of tetraphenylborate decomposition products. If the yellow color was primarily due to chromate (present at $488 \pm 19 \mathrm{mg} / \mathrm{L}$ based on chromium content from ICP-ES analysis reported in Appendix 1 ), then the acidified solution should be orange colored.

Researchers discarded all excess filtrate. Personnel recapped the test bottle and returned it to the waterbath. The total time outside of the waterbath for sampling did not exceed 3 minutes. Personnel then capped the glass sample vial, gently agitated it, and allowed it to 
stand at ambient laboratory temperature. In the $4.5 \mathrm{M}$ Na solutions all solids readily dissolved, but the 7.5 M Na solutions required occasional agitation and two separate 1-mL

additions of $5 \mathrm{M}$ nitric acid. Personnel left the samples taken after 8 hours, which received the first $4 \mathrm{~mL}$ acid addition almost immediately, overnight without agitation. These samples required the addition of more nitric acid solution the following day to dissolve the solids.

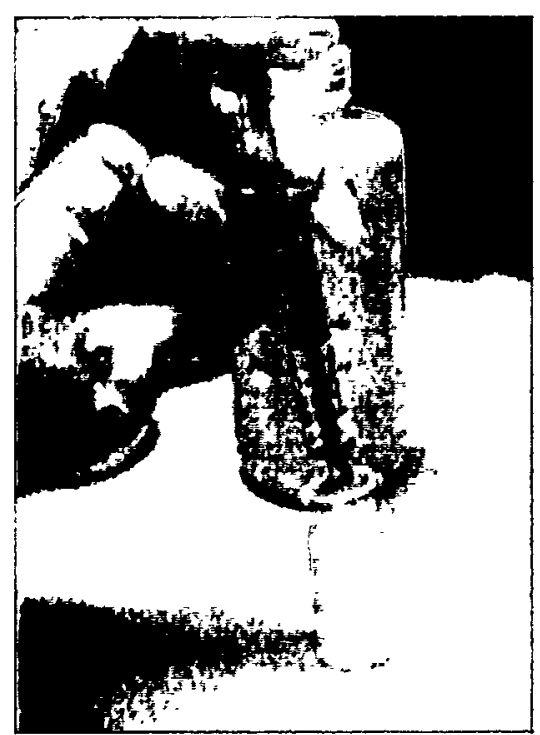

Solids removal occurred by filtering the suspension through a $0.45-\mu \mathrm{m}$ pore size syringe filter.

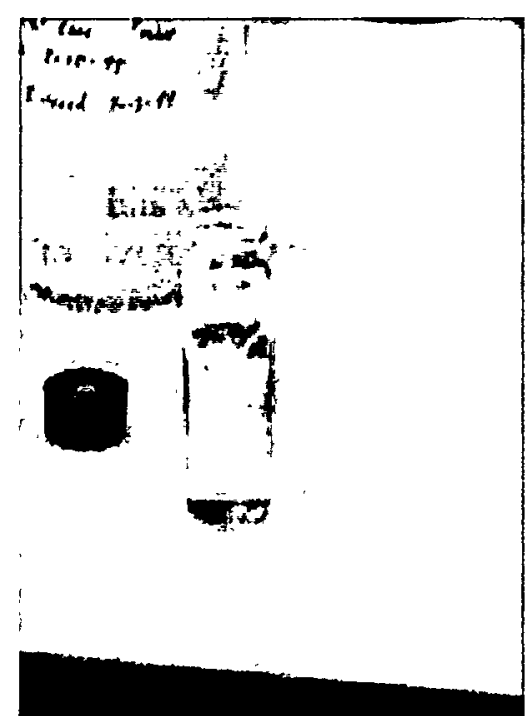

A white precipitate also forms upon mixing the filtered solution with $5 \mathrm{M}$ nitric acid.

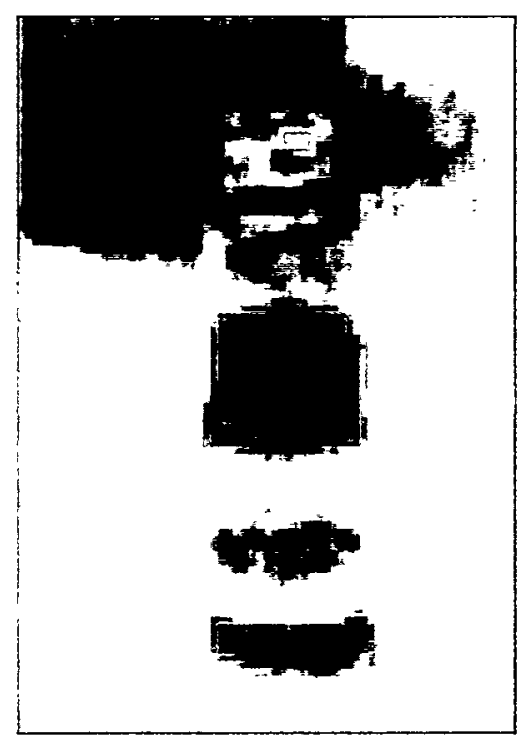

A brown gas $\left(\mathrm{NO}_{\mathrm{x}}\right)$ forms upon mixing the filtered sample with $5 \mathrm{M}$ nitric acid.

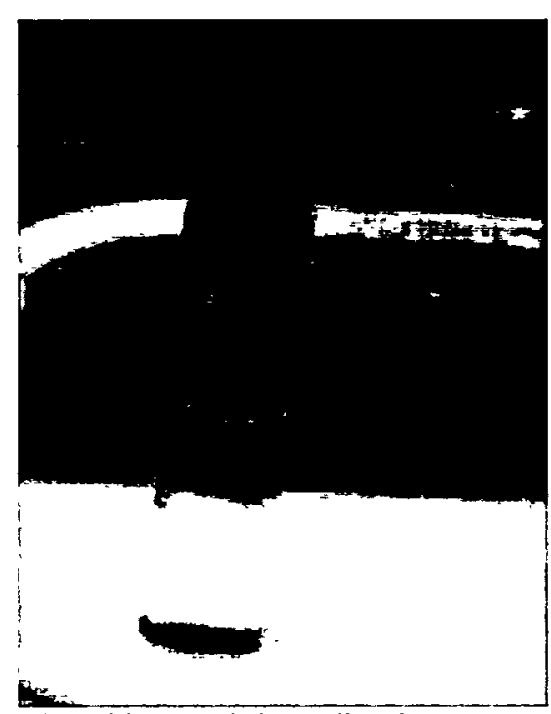

The white precipitate dissolves upon standing producing a clear colorless solution. 
The Analytical Development Section of SRTC performed the analyses. Strontium-85 activity measurement occurred by gamma pulse height spectroscopy. Personnel determined concentrations ${ }^{237} \mathrm{~Np}$ and uranium isotopes by Inductively Coupled Plasma Mass Spectroscopy (ICP-MS) analysis. ${ }^{239 / 240} \mathrm{Pu}$ and ${ }^{238} \mathrm{Pu}$ activity determinations relied on alpha spectroscopy after chemically separating the plutonium from the neptunium.

\section{Results and Discussion}

Researchers performed duplicate tests with each waste solution at $0.2 \mathrm{~g} / \mathrm{L}$ MST and a single control solution with no MST. Table III shows the test design with MST concentrations as defined in the task technical and quality assurance plan for this work [7]. Note that these tests were carried out in the presence of sodium tetraphenylborate. Although not measured analytically, we postulate that tetraphenylborate decomposition products are also present in the treated waste solution (see Experimental Section). Previous simulant tests indicated the addition of sodium tetraphenylborate did not significantly affect the extent of rate of sorbate removal [4].

Table III. Test Parameters

\begin{tabular}{cccc} 
Bottle \# & [Na $](\mathrm{M})$ & $\begin{array}{c}\text { MST Concentration }(\mathrm{g} / \mathrm{L}) \\
\text { Target }\end{array}$ & $\begin{array}{c}\text { Actual } \\
1\end{array}$ \\
\hline 1.5 & & 0.0 & 0.0 \\
2 & 7.5 & 0.2 & 0.200 \\
3 & 7.5 & 0.2 & 0.201 \\
& & & \\
4 & 4.5 & 0.0 & 0.0 \\
5 & 4.5 & 0.2 & 0.199 \\
6 & 4.5 & 0.2 & 0.199
\end{tabular}

\section{Control Samples}

The experiment used one test bottle of each sodium solution (\#1 @ $7.5 \mathrm{M} \mathrm{Na}$ and \#4 @ 4.5M Na) containing no MST to serve as control tests to correct for removal of sorbates by sorption onto the bottle walls, the filter or by precipitation. No systematic changes in the sorbate concentrations appeared over the duration of the experiments for either the $7.5 \mathrm{M}$ or $4.5 \mathrm{M} \mathrm{Na}^{+}$solutions (see Figures $2-5$ ). These results indicate no significant removal of sorbate in the control samples. For this reason, the results for tests with MST do not require correction for removal by mechanisms other than that by sorption with MST.

Table IV provides the calculated average, standard deviation and percent relative error for each sorbate in the control samples. The relative errors for the sorbates remained below $10 \%$ in all cases except for neptunium. Relative errors proved lower for the $4.5 \mathrm{M}$ Na solution compared to the $7.5 \mathrm{M} \mathrm{Na}$ solution. We attribute the higher relative errors in the $7.5 \mathrm{M} \mathrm{Na}$ solution primarily to the more concentrated salt matrix and greater dilution factor required in acidifying samples. 
Researchers diluted the 7.5M Na solution to prepare the $4.5 \mathrm{M} \mathrm{Na}$ solution. No evidence of solids formation occurred during dilution. Thus, the ratio of the sorbate concentrations in the diluted and concentrated solution should measure 0.600 . Table $V$ provides the average and standard deviation of the ratios of the sorbates in Bottle \#4 to those in Bottle \#1. Strontium and plutonium exhibited good agreement to the theoretical value of 0.600 . Uranium and neptunium did not exhibit good agreement with the theoretical value.

Since strontium and plutonium measurements derive from independent methods and exhibited good agreement, we conclude the poorer agreement for uranium and neptunium does result from a systematic error in the sampling method. Researchers identified problems in the ICP-MS analytical results from inspection of the results obtained from the control samples. Consequently, personnel repeated analyses of all samples by the ICP-MS method. The reported ICP-MS results for uranium and neptunium are those values reported from the second determination. The relative error for uranium slightly exceeds that obtained for strontium and plutonium by the two independent radiochemical counting methods (see Table IV). The neptunium results indicate a significantly higher error compared to the other sorbates. The Analytical Development Section researchers reported the samples from the current study required a larger dilution than necessary the previous simulant testing. The solution matrix in the radioactive waste samples contains many more compounds than the simulated waste solution including tetraphenylborate decomposition products. Thus, we attribute the larger errors in the ICP-MS analytical results compared to the radiochemical results for strontium and plutonium to the larger dilution factors and matrix affects.

Table IV. Sorbate Concentrations in Control Samples

\begin{tabular}{|c|c|c|c|c|}
\hline \multicolumn{5}{|c|}{ Concentration $(\mu \mathrm{g} / \mathrm{L})$} \\
\hline$[\mathrm{Na}](\mathrm{M})$ & Sorbate & Average & Std. Dev. & $\%$ RSD \\
\hline 7.5 & Strontium & 41.0 & 2.03 & 4.94 \\
\hline 4.5 & Strontium & 24.6 & 0.742 & 3.01 \\
\hline 7.5 & Plutonium & 13.5 & 1.02 & 7.55 \\
\hline 4.5 & Plutonium. & 8.22 & 0.22 & 2.67 \\
\hline 7.5 & Uranium & 11,500 & 876 & 7.64 \\
\hline 4.5 & Uranium & 5,860 & 319 & 5.45 \\
\hline 7.5 & Neptunium & 389 & 95.5 & 24.5 \\
\hline 4.5 & Neptunium & 174 & 22.7 & 13.1 \\
\hline
\end{tabular}


Table V. Ratios of Sorbate Concentration in Bottle \#4 to that in Bottle \#1

$\begin{array}{lc}\text { Sorbate }_{\text {Strontium }} & \text { Average Ratio }^{\text {a }} \\ \text { Plutonium } & 0.604 \pm 0.028 \\ \text { Uranium } & 0.625 \pm 0.046 \\ \text { Neptunium } & 0.496 \pm 0.049 \\ & 0.422 \pm 0.129 \\ { }^{\text {a average and standard deviation of ratios }} \\ \text { determined for each individual measurement }\end{array}$

Figure 2. Strontium Concentrations in Control Samples (Bottles \#1 and \#4)

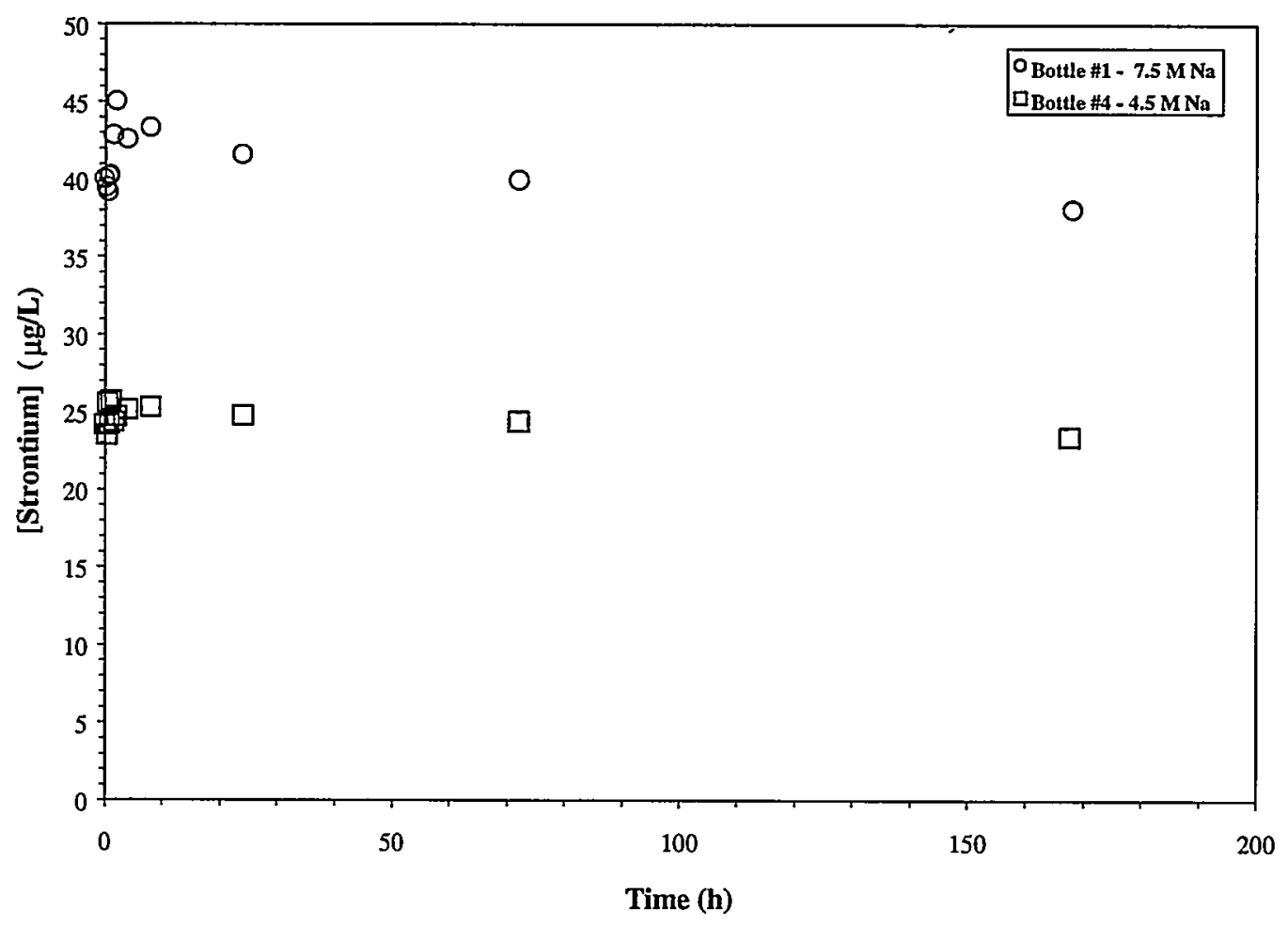


Figure 3. Plutonium Concentrations in Control Samples (Bottles \#1 and \#4)

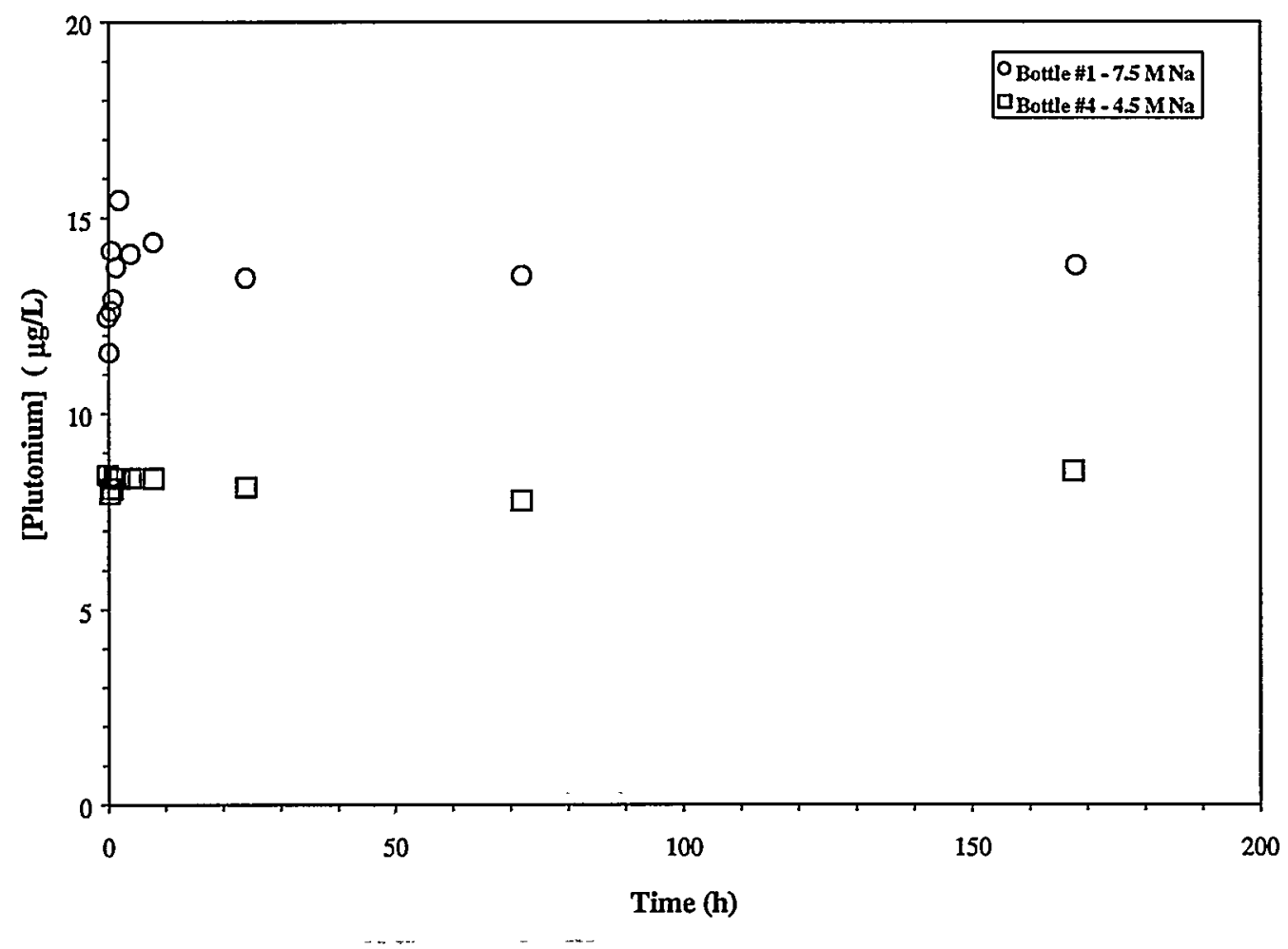

Figure 4. Uranium Concentrations in Control Samples (Bottles \#1 and \#4)

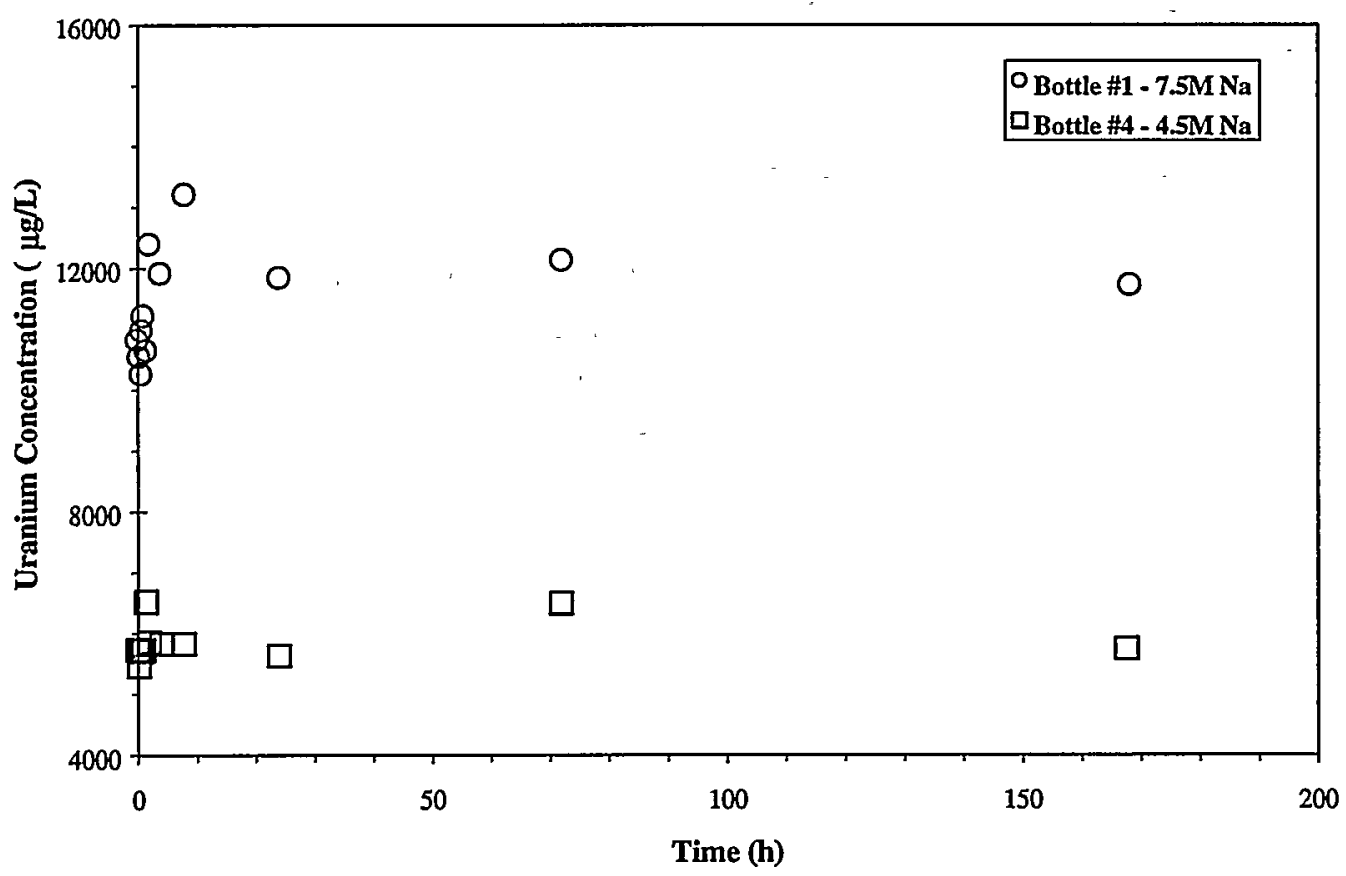


Figure 5. Neptunium Concentrations in Control Samples (Bottles \#1 and \#4)

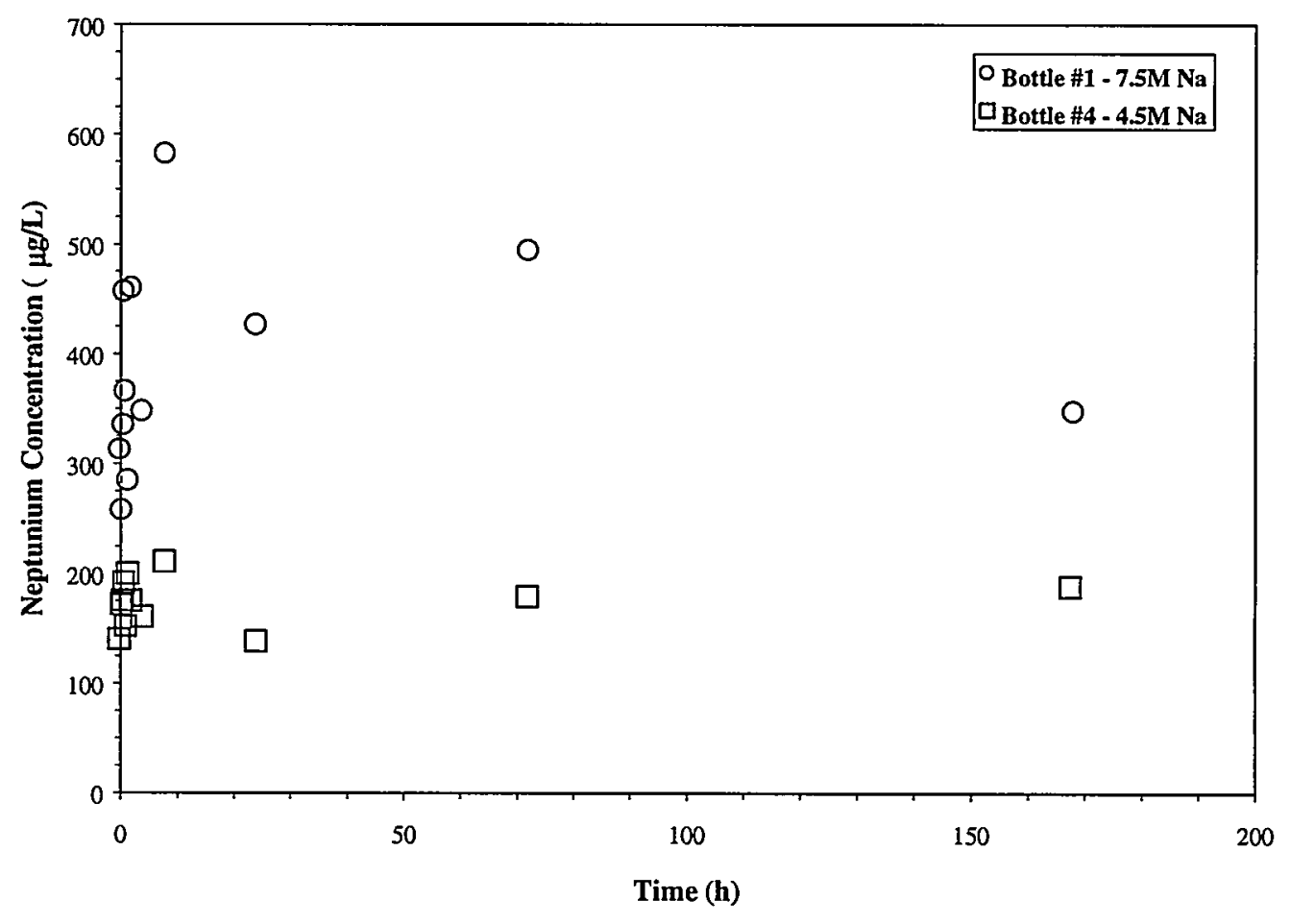

Strontium Removal

Strontium removal occurred at both sodium ion concentrations. Figure 6 provides a graph of the average total strontium concentration versus time for both sodium ion concentrations. As previously observed with simulated waste solutions, the relative extent of strontium removal increased at lower sodium concentration [4,5].

Results indicated that the slurries met the Z-Area Feed Limits at both ionic strengths and at $0.2 \mathrm{~g} / \mathrm{L}$ MST assuming a ${ }^{90} \mathrm{Sr}$ content of 5.2 atomic percent. At the higher assumed ${ }^{90} \mathrm{Sr}$ content ( 45 atomic \%), the higher ionic strength solution $(7.5 \mathrm{M} \mathrm{Na}$ ) fails to achieve the Z-Area limit. Note that the estimated ${ }^{90} \mathrm{Sr}$ content of the waste solutions at the start of the MST adsorption tests are 120 and $72 \mathrm{nCi} / \mathrm{g}$ for the $7.5 \mathrm{M}$ and $4.5 \mathrm{M}$ sodium concentration solutions, respectively. Both of these values are above the Z-Area limit of $40 \mathrm{nCi} / \mathrm{g}$ indicating the waste required strontium removal at both ionic strengths [8]. Based on the required decontamination factors, strontium removal achieved the Z-Area Feed Limit within 1.02 hours at $7.5 \mathrm{M} \mathrm{Na}$ concentration and 0.30 hours at $4.5 \mathrm{M} \mathrm{Na}$ concentration. 
Figure 6. Average Strontium Removal from Radioactive Waste Solutions Diluted to 4.5M and 7.5M in Sodium

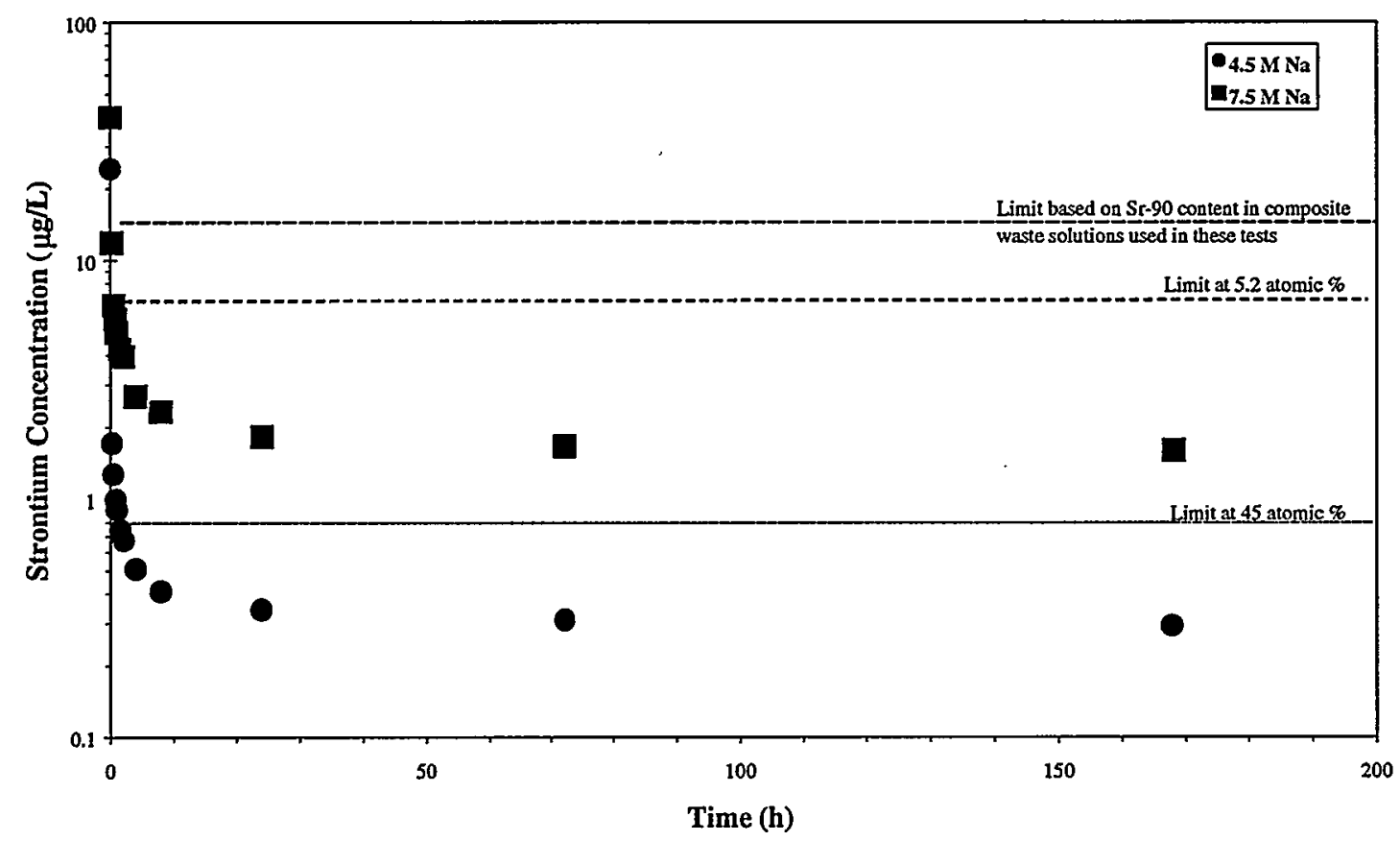

Table VI presents the average and single standard deviation for the elapsed times, total strontium concentrations and decontamination factors measured at both ionic strength solutions. Appendices 2-7 provide experimental results for the individual tests. From the calculated decontamination factors, we determined the distribution constants, $\mathrm{K}_{d}$, at 1.20 $\pm 0.025 \times 10^{5}(7.5 \mathrm{M} \mathrm{Na})$ and $4.12 \pm 0.11 \times 10^{5}(4.5 \mathrm{M} \mathrm{Na}) \mathrm{mL}$. These values agree with those previously measured for strontium in simulated waste solutions (see Appendix 4 in reference 4). 


\section{Table VI . Average Strontium Concentrations and Decontamination Factors in Radioactive Waste Tests}

\begin{tabular}{|c|c|c|c|c|c|}
\hline & & $\mathrm{Na}]=7.5 \mathrm{M}$ & & & \\
\hline $\begin{array}{l}\text { Elapsed Time } \\
\text { Average } \\
\text { Time (h) }\end{array}$ & $\begin{array}{l}\text { Elapsed Time } \\
\text { Std. Dev. } \\
\text { (h) }\end{array}$ & $\begin{array}{c}\text { [Total Sr] } \\
\text { Average } \\
(\mu \mathrm{g} / \mathrm{L})\end{array}$ & $\begin{array}{c}\text { [Total Sr] } \\
\text { Std. Dev. } \\
(\mu \mathrm{g} / \mathrm{L})\end{array}$ & $\begin{array}{c}\mathrm{DF} \\
\text { Average }\end{array}$ & $\begin{array}{c}\text { DF } \\
\text { Std. Dev. }\end{array}$ \\
\hline $0.00 \mathrm{E}+00$ & $0.00 \mathrm{E}+00$ & $4.00 \mathrm{E}+01$ & $0.00 \mathrm{E}+00$ & $1.00 \mathrm{E}+00$ & $0.00 \mathrm{E}+00$ \\
\hline 2.42E-01 & $1.18 \mathrm{E}-02$ & $1.19 \mathrm{E}+01$ & $2.81 E+\infty 0$ & $3.45 \mathrm{E}+00$ & $8.15 \mathrm{E}-01$ \\
\hline $5.92 \mathrm{E}-01$ & $1.18 \mathrm{E}-02$ & $6.49 \mathrm{E}+00$ & $2.29 \mathrm{E}+00$ & $6.57 E+00$ & $2.32 \mathrm{E}+00$ \\
\hline $8.25 \mathrm{E}-01$ & $1.18 \mathrm{E}-02$ & $5.71 \mathrm{E}+00$ & $1.61 \mathrm{E}+00$ & $7.30 \mathrm{E}+00$ & $2.06 \mathrm{E}+00$ \\
\hline $1.02 E+00$ & $9.43 \mathrm{E}-02$ & $4.97 \mathrm{E}+00$ & $1.96 \mathrm{E}+00$ & $8.72 \mathrm{E}+00$ & $3.44 \mathrm{E}+00$ \\
\hline $1.53 \mathrm{E}+00$ & $0.00 \mathrm{E}+00$ & $4.25 \mathrm{E}+00$ & $1.52 \mathrm{E}+00$ & $1.00 \mathrm{E}+01$ & $3.59 \mathrm{E}+00$ \\
\hline $2.04 \mathrm{E}+00$ & $5.89 \mathrm{E}-02$ & $3.97 \mathrm{E}+00$ & $1.09 \mathrm{E}+00$ & $1.05 \mathrm{E}+01$ & $2.88 \mathrm{E}+00$ \\
\hline $4.07 \mathrm{E}+00$ & $4.71 \mathrm{E}-02$ & $2.70 \mathrm{E}+00$ & $7.86 \mathrm{E}-01$ & $1.55 \mathrm{E}+01$ & $4.51 \mathrm{E}+00$ \\
\hline $8.01 \mathrm{E}+00$ & $1.18 \mathrm{E}-02$ & $2.32 \mathrm{E}+00$ & $4.86 \mathrm{E}-01$ & $1.76 \mathrm{E}+01$ & $3.70 E+00$ \\
\hline $2.41 E+01$ & $2.36 \mathrm{E}-02$ & $1.83 \mathrm{E}+00$ & $2.14 \mathrm{E}-01$ & $2.20 \mathrm{E}+01$ & $2.58 \mathrm{E}+00$ \\
\hline $7.21 \mathrm{E}+01$ & $8.25 \mathrm{E}-02$ & $1.66 \mathrm{E}+00$ & $1.08 \mathrm{E}-01$ & $2.41 \mathrm{E}+01$ & $1.57 E+00$ \\
\hline $1.68 \mathrm{E}+02$ & $1.89 \mathrm{E}-01$ & $1.59 \mathrm{E}+00$ & $3.97 \mathrm{E}-02$ & $2.51 \mathrm{E}+01$ & $6.26 \mathrm{E}-01$ \\
\hline & & {$[\mathrm{Na}]=4.5$} & & & \\
\hline Elapsed Time & Elapsed Time & [Total Sr] & [Total Sr] & DF & $\mathrm{DF}$ \\
\hline $\begin{array}{l}\text { Average } \\
\text { (h) }\end{array}$ & $\begin{array}{l}\text { Std. Dev. } \\
\text { (h) }\end{array}$ & $\begin{array}{c}\text { Average } \\
(\mu \mathrm{g} / \mathrm{L}\end{array}$ & $\begin{array}{c}\text { Std. Dev. } \\
(\mu \mathrm{g} / \mathrm{L})\end{array}$ & Average & Std. Dev. \\
\hline $0.00 \mathrm{E}+00$ & $0.00 \mathrm{E}+00$ & $2.42 \mathrm{E}+01$ & $0.00 \mathrm{E}+00$ & $1.00 \mathrm{E}+00$ & $0.00 \mathrm{E}+00$ \\
\hline $3.00 \mathrm{E}-01$ & $7.07 \mathrm{E}-02$ & $1.71 E+00$ & $4.24 \mathrm{E}-01$ & $1.46 \mathrm{E}+01$ & $3.62 E+00$ \\
\hline $4.75 \mathrm{E}-01$ & $8.25 \mathrm{E}-02$ & $1.27 \mathrm{E}+00$ & $3.75 \mathrm{E}-01$ & $1.99 \mathrm{E}+01$ & $5.87 \mathrm{E}+00$ \\
\hline $8.67 \mathrm{E}-01$ & $2.36 \mathrm{E}-02$ & $9.94 \mathrm{E}-01$ & $3.69 \mathrm{E}-01$ & $2.61 \mathrm{E}+01$ & $9.71 E+00$ \\
\hline $1.03 E+00$ & $1.18 \mathrm{E}-02$ & $8.97 \mathrm{E}-01$ & 2.77E-01 & $2.83 \mathrm{E}+01$ & $8.73 E+00$ \\
\hline $1.54 \mathrm{E}+00$ & $8.25 \mathrm{E}-02$ & $7.40 \mathrm{E}_{-} 01$ & 2.02E-01 & $3.39 \mathrm{E}+01$ & $9.26 \mathrm{E}+00$ \\
\hline $2.02 E+00$ & $0.00 E+00$ & $6.70 \mathrm{E}-01$ & $1.65 \mathrm{E}-01$ & $3.72 \mathrm{E}+01$ & $9.15 \mathrm{E}+00$ \\
\hline $4.04 \mathrm{E}+00$ & $1.06 \mathrm{E}-01$ & $5.08 \mathrm{E}-01$ & $1.17 \mathrm{E}-01$ & $4.89 \mathrm{E}+01$ & $1.12 \mathrm{E}+01$ \\
\hline $8.02 E+00$ & $1.18 \mathrm{E}-02$ & $4.09 \mathrm{E}-01$ & $5.93 \mathrm{E}-02$ & 5.97E+01 & $8.65 \mathrm{E}+00$ \\
\hline $2.40 \mathrm{E}+01$ & $3.54 \mathrm{E}-02$ & $3.43 \mathrm{E}-01$ & $3.39 \mathrm{E}-02$ & $7.08 \mathrm{E}+01$ & $6.99 \mathrm{E}+00$ \\
\hline $7.20 \mathrm{E}+01$ & $9.43 \mathrm{E}-02$ & $3.11 \mathrm{E}-01$ & $2.23 \mathrm{E}-02$ & $7.80 \mathrm{E}+01$ & $5.59 \mathrm{E}+00$ \\
\hline $1.68 \mathrm{E}+02$ & $4.71 \mathrm{E}-02$ & $2.92 \mathrm{E}-01$ & $3.10 \mathrm{E}-02$ & $8.33 \mathrm{E}+01$ & $8.84 \mathrm{E}+00$ \\
\hline
\end{tabular}

Figure 7 presents the average strontium concentration versus time data in the radioactive waste tests as well as that for previously reported simulated waste solutions $[4,5]$. The plot omits the initial strontium concentrations to allow a log-log presentation of the data. A significant change in the slope of the curve occurs between 8 and 24 hours of contact with the MST. This result suggests that equilibrium nearly occurred during this time period resulting in a significant decrease in the rate of strontium removal.

Inspection of the graphs indicates that the rate of strontium removal in the radioactive waste solutions appears very similar to that in the simulated waste solutions for both ionic strength conditions. Thus, we conclude that the strontium removal rate data obtained from simulated waste solutions proves reliable in design calculations. 
Figure 7. Comparison of Strontium Removal in Radioactive Waste and Simulated Waste Solutions

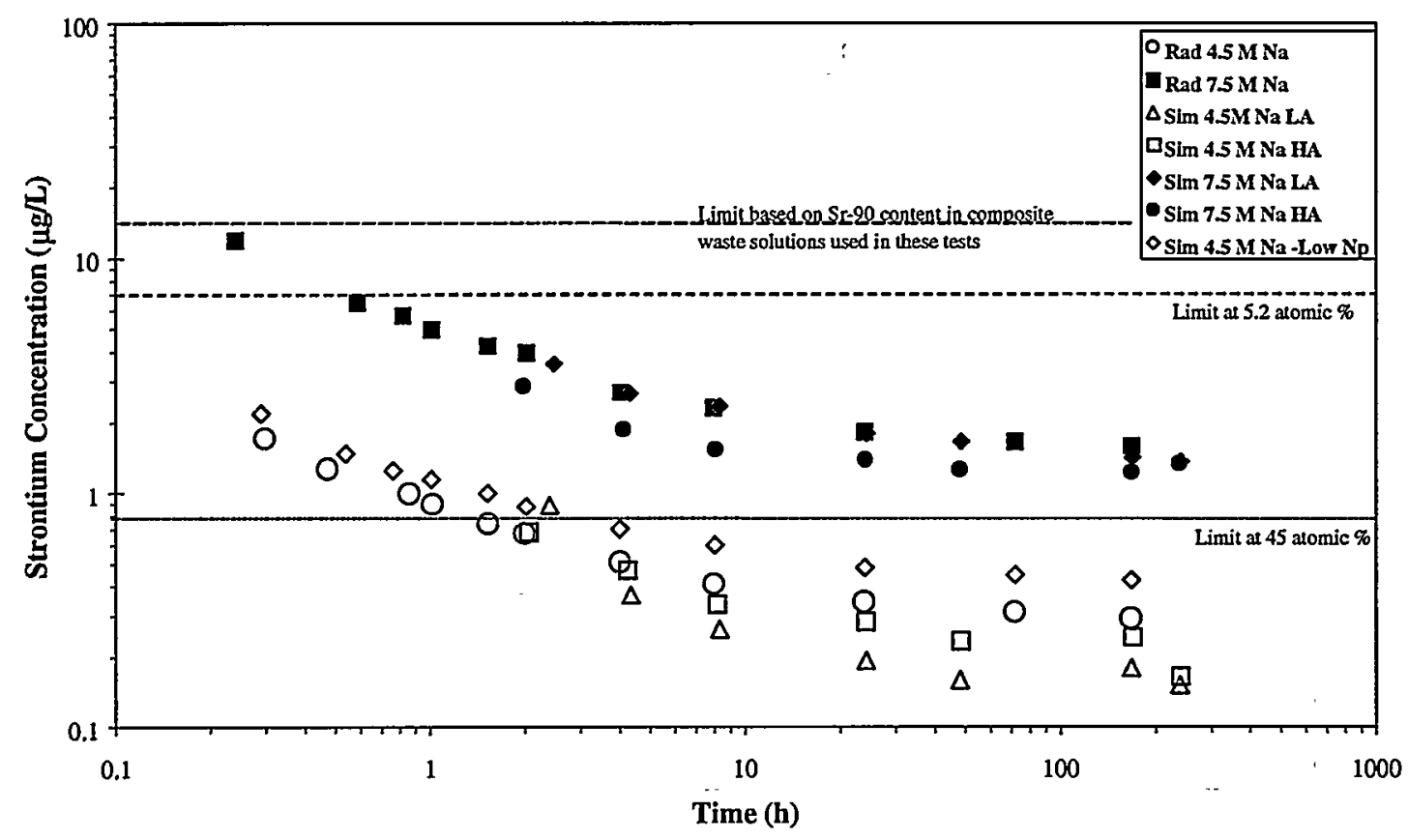

Plutonium Removal

Plutonium removal occurred in both radioactive waste ionic strength solutions. Figure 8 provides a graph of the average total plutonium concentration versus time for both sodium ion concentrations. As previously observed with simulated salt solution, the relative extent of plutonium removal increased at the lower sodium concentration $[4,5]$.

Researchers did not add plutonium to the waste solution except for trace amounts present in the ${ }^{237} \mathrm{~Np}$ solution added to increase the ${ }^{237} \mathrm{~Np}$ concentration. Based on radiochemical and mass spectroscopy analyses, the composite waste solution contained $0.337 \pm 0.0057$ grams $\mathrm{Pu}-238$ per gram of total plutonium. The neptunium activity analyzed at 0.182 $\mathrm{nCi} / \mathrm{g}$ in the $7.5 \mathrm{M}$ Na solution and $0.0815 \mathrm{nCi} / \mathrm{g}$ in the $4.5 \mathrm{M}$ Na solution. Thus, ${ }^{238} \mathrm{Pu}$ accounts for $>99 \%$ of the alpha activity in the waste solutions. The initial alpha activity of the waste solutions measured $59 \mathrm{nCi} / \mathrm{g}$ for the $7.5 \mathrm{M} \mathrm{Na}$ solution and $39 \mathrm{nCi} / \mathrm{g}$ for the 4.5 M Na solution.

Table VII presents the averages and single standard deviations for the elapsed times, total plutonium concentrations and decontamination factors for both ionic strength solutions. Appendices 2-7 provide experimental results for the individual tests. From the calculated decontamination factors, we determined the distribution constants, $K_{d}$, at $6000 \pm 110$ $(7.5 \mathrm{M} \mathrm{Na})$ and $44000 \pm 2600(4.5 \mathrm{M} \mathrm{Na}) \mathrm{mL} / \mathrm{g}$. These values agree with those previously measured for plutonium in simulated waste solutions (see Appendix 4 in reference 4]. 
Figure 8. Average Plutonium Removal from Radioactive Waste Solutions Diluted to $4.5 \mathrm{M}$ and $7.5 \mathrm{M}$ in Sodium

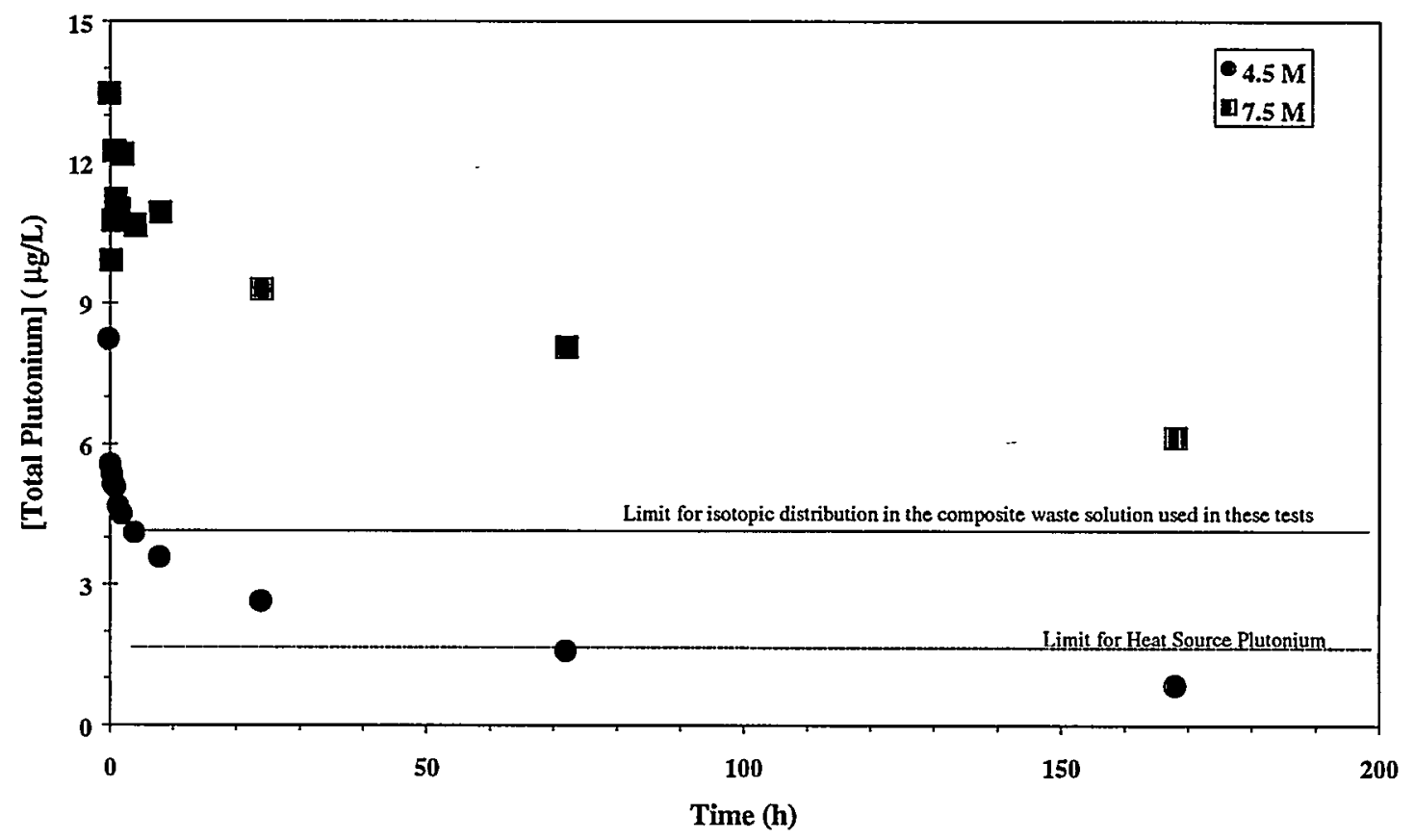

The Z-Area has a limit for total alpha activity of $20 \mathrm{nCi} / \mathrm{g}$ [8]. Based on the measured decontamination factors, the total plutonium activity in the $4.5 \mathrm{M} \mathrm{Na}$ and $7.5 \mathrm{M} \mathrm{Na}$ waste solutions decreased to $4.1 \pm 0.21 \mathrm{nCi} / \mathrm{g}$ and $27 \pm 0.5 \mathrm{nCi} / \mathrm{g}$, respectively, at equilibrium. Thus, the $4.5 \mathrm{M} \mathrm{Na}$ waste solution, but not the $7.5 \mathrm{M} \mathrm{Na}$ waste solution, achieved the ZArea limit for total alpha activity. On average, the $4.5 \mathrm{M} \mathrm{Na}$ waste solution achieved the Z-Area limit 4.07 hours after the addition of $0.2 \mathrm{~g} / \mathrm{L}$ MST (see Table VII). 


\section{Table VII. Average Plutonium Concentrations and Decontamination Factors in Radioactive Waste Tests}

\begin{tabular}{|c|c|c|c|c|c|}
\hline & & {$[\mathrm{Na}]=$ ? } & & & \\
\hline $\begin{array}{c}\text { Elapsed Time } \\
\text { Average } \\
\text { (h) }\end{array}$ & $\begin{array}{c}\text { Elapsed Time } \\
\text { Std. Dev. } \\
\text { Time (h) }\end{array}$ & $\begin{array}{c}\text { [Total Pu] } \\
\text { Average } \\
(\mu \mathrm{g} / \mathrm{L}) \\
\end{array}$ & $\begin{array}{c}\text { [Total Pu] } \\
\text { Std. Dev. } \\
(\mu g / L)\end{array}$ & $\begin{array}{c}\mathrm{DF} \\
\text { Average }\end{array}$ & $\begin{array}{c}\text { DF } \\
\text { Std. Dev. }\end{array}$ \\
\hline $0.00 \mathrm{E}+00$ & $0.00 \mathrm{E}+00$ & $1.35 E+01$ & $0.00 \mathrm{E}+00$ & $1.00 \mathrm{E}+00$ & $0.00 \mathrm{E}+00$ \\
\hline $2.42 \mathrm{E}-01$ & $1.18 \mathrm{E}-02$ & $9.91 E+00$ & 5.31E-01 & $1.36 \mathrm{E}+00$ & $7.28 \mathrm{E}-02$ \\
\hline $5.92 \mathrm{E}-01$ & 1.18E-02 & $1.08 \mathrm{E}+01$ & $2.65 \mathrm{E}-01$ & $1.25 \mathrm{E}+00$ & $3.09 \mathrm{E}-02$ \\
\hline $8.25 \mathrm{E}-01$ & $1.18 \mathrm{E}-02$ & $1.22 \mathrm{E}+01$ & $5.59 \mathrm{E}-02$ & $1.10 \mathrm{E}+00$ & $5.02 \mathrm{E}-03$ \\
\hline $1.02 \mathrm{E}+00$ & $9.43 \mathrm{E}-02$ & $1.12 \mathrm{E}+01$ & $8.38 \mathrm{E}-01$ & $1.20 \mathrm{E}+00$ & $8.99 \mathrm{E}-02$ \\
\hline $1.53 \mathrm{E}+00$ & $0.00 \mathrm{E}+00$ & $1.10 \mathrm{E}+01$ & 4.47E-01 & $122 \mathrm{E}+00$ & $4.98 \mathrm{E}-02$ \\
\hline $2.04 \mathrm{E}+00$ & $5.89 \mathrm{E}-02$ & $1.22 \mathrm{E}+01$ & $5.87 \mathrm{E}-01$ & $1.11 \mathrm{E}+00$ & $5.34 \mathrm{E}-02$ \\
\hline $4.07 \mathrm{E}+00$ & $4.71 \mathrm{E}-02$ & $1.07 \mathrm{E}+01$ & $1.82 \mathrm{E}-01$ & $1.26 \mathrm{E}+00$ & $2.15 \mathrm{E}-02$ \\
\hline $8.01 E+00$ & $1.18 \mathrm{E}-02$ & $1.09 \mathrm{E}+01$ & $1.92 \mathrm{E}-01$ & $1.23 E+00$ & $2.17 \mathrm{E}-02$ \\
\hline $2.41 E+01$ & $2.36 \mathrm{E}-02$ & $9.30 \mathrm{E}+00$ & 2.51E-01 & $1.45 \mathrm{E}+00$ & $3.91 \mathrm{E}-02$ \\
\hline $7.21 \mathrm{E}+01$ & $8.25 \mathrm{E}-02$ & $8.06 \mathrm{E}+00$ & $1.12 \mathrm{E}-01$ & $1.67 \mathrm{E}+00$ & $2.32 \mathrm{E}-02$ \\
\hline $1.68 E+02$ & $1.89 \mathrm{E}-01$ & $6.14 \mathrm{E}+00$ & $1.12 \mathrm{E}-01$ & $2.19 \mathrm{E}+00$ & $3.99 \mathrm{E}-02$ \\
\hline & & {$[\mathrm{Na}]=4.5 \mathrm{M}$} & & & - \\
\hline Elapsed Time & Elapsed Time & [Total Pu] & [Total Pu] & $\mathrm{DF}$ & DF \\
\hline $\begin{array}{l}\text { Average } \\
\text { (h) }\end{array}$ & $\begin{array}{l}\text { Std. Dev. } \\
\text { Time (h) }\end{array}$ & $\begin{array}{l}\text { Average } \\
(\mu \mathrm{g} / \mathrm{L})\end{array}$ & $\begin{array}{c}\text { Std. Dev. } \\
(\mu g / L)\end{array}$ & Average & Std. Dev. \\
\hline $0.00 \mathrm{E}+00$ & $0.00 \mathrm{E}+00$ & $8.22 \mathrm{E}+00$ & $0.00 \mathrm{E}+00$ & $1.00 \mathrm{E}+00$ & $0.00 \mathrm{E}+00$ \\
\hline $3.00 \mathrm{E}-01$ & $7.07 \mathrm{E}-02$ & $5.55 \mathrm{E}+00$ & $6.12 \mathrm{E}-01$ & $1.49 E+00$ & $1.64 \mathrm{E}-01$ \\
\hline $4.75 \mathrm{E}-01$ & $8.25 \mathrm{E}-02$ & $5.35 \mathrm{E}+00$ & $3.72 \mathrm{E}-01$ & $1.54 \mathrm{E}+00$ & $1.07 \mathrm{E}-01$ \\
\hline $8.67 \mathrm{E}-01$ & $2.36 \mathrm{E}-02$ & $5.13 E+00$ & $1.97 \mathrm{E}-01$ & $1.60 \mathrm{E}+00$ & $6.14 \mathrm{E}-02$ \\
\hline $1.03 \mathrm{E}+00$ & $1.18 \mathrm{E}-02$ & $5.07 \mathrm{E}+00$ & $2.62 \mathrm{E}-01$ & $1.62 \mathrm{E}+00$ & $8.40 \mathrm{E}-02$ \\
\hline $1.54 \mathrm{E}+00$ & $8.25 \mathrm{E}-02$ & $4.66 \mathrm{E}+00$ & $5.47 \mathrm{E}-02$ & $1.76 \mathrm{E}+00$ & $2.07 \mathrm{E}-02$ \\
\hline $2.02 E+00$ & $0.00 \mathrm{E}+00$ & $4.49 \mathrm{E}+00$ & $1.64 \mathrm{E}_{-01}$ & $1.83 E+00$ & $6.69 \mathrm{E}-02$ \\
\hline $4.04 \mathrm{E}+00$ & $1.06 \mathrm{E}-01$ & $4.10 \mathrm{E}+00$ & $8.75 \mathrm{E}-02$ & $2.01 \mathrm{E}+00$ & $4.28 \mathrm{E}-02$ \\
\hline $8.02 \mathrm{E}+00$ & $1.18 \mathrm{E}-02$ & $3.57 \mathrm{E}+00$ & $2.19 E-02$ & $2.30 \mathrm{E}+00$ & $1.41 \mathrm{E}-02$ \\
\hline $2.40 \mathrm{E}+01$ & $3.54 \mathrm{E}-02$ & $2.64 \mathrm{E}+00$ & $6.56 \mathrm{E}-02$ & $3.11 E+00$ & 7.72E-02 \\
\hline $7.20 E+01$ & $9.43 \mathrm{E}-02$ & $1.58 \mathrm{E}+00$ & $6.23 \mathrm{E}-02$ & $5.21 \mathrm{E}+00$ & $2.05 \mathrm{E}-01$ \\
\hline $1.68 \mathrm{E}+02$ & 4.71E-02 & $8.49 \mathrm{E}-01$ & 4.37E-02 & $9.70 E+00$ & $5.00 \mathrm{E}-01$ \\
\hline
\end{tabular}

Figure 9 presents the average plutonium concentration versus time data in the radioactive waste test as well as that for previously reported simulated waste solution at $4.5 \mathrm{M}$ in sodium concentration. The graph omits the initial plutonium concentrations to allow a $\log -\log$ plot. Inspection of the graphs indicates that the rate of plutonium removal in the radioactive waste solution behaves similarly to that in the simulated waste solution. In both the non-radioactive and radioactive solutions, the plutonium removal rate changes significantly at about 24 hours. We attribute the lower removal rate in the radioactive waste solution during the first 24 hours to the lower initial plutonium concentration in the radioactive waste solution $(8.22 \mu \mathrm{g} / \mathrm{L})$ compared to that in the simulated waste solution $(63.5 \mu \mathrm{g} / \mathrm{L})$.

Unlike strontium, the concentration of plutonium continues to decrease over the entire test period (168 hours) indicating the slurry did not reach equilibrium when the test completed. We attribute the slowness in achieving equilibrium to the presence of multiple plutonium oxidation states and species in solution $[9,10]$. As the predominant plutonium species in solution adsorbs onto the MST, the system tries to achieve chemical equilibrium producing more plutonium available for adsorption. The rate of conversion 
of the plutonium species appears slower than that for adsorption to exhibit the observed behavior.

Plutonium removal rate proved more difficult to ascertain in the $7.5 \mathrm{M}$ Na waste solution than in the $4.5 \mathrm{M}$ waste solution. Given the scatter in the plutonium concentrations in the control sample (see Figure 3) and in the 7.5M Na waste solutions (see Figure 8) during the first 8 hours, statistically significant plutonium removal occurs sometime after eight hours of contact with the MST. As observed at the lower ionic strength test (4.5M Na), the concentration of plutonium in the $7.5 \mathrm{M} \mathrm{Na}$ waste solution continues to decrease over the entire test period (168 hours) indicating the slurry did not reach equilibrium when the test completed.

Because of the large errors in the plutonium concentrations in the previously reported simulant testing [4], we could not compare the plutonium removal rates between the simulated and radioactive waste solutions at the higher ionic strength. However, based on the $4.5 \mathrm{M} \mathrm{Na}$ waste solution results, we conclude that the plutonium removal rate data obtained from simulated waste solutions provides reliable data for use in design calculations.

\section{Figure 9. Comparison of Plutonium Removal in Radioactive Waste and Simulated} Waste Solutions at $4.5 \mathrm{M}$ in Sodium

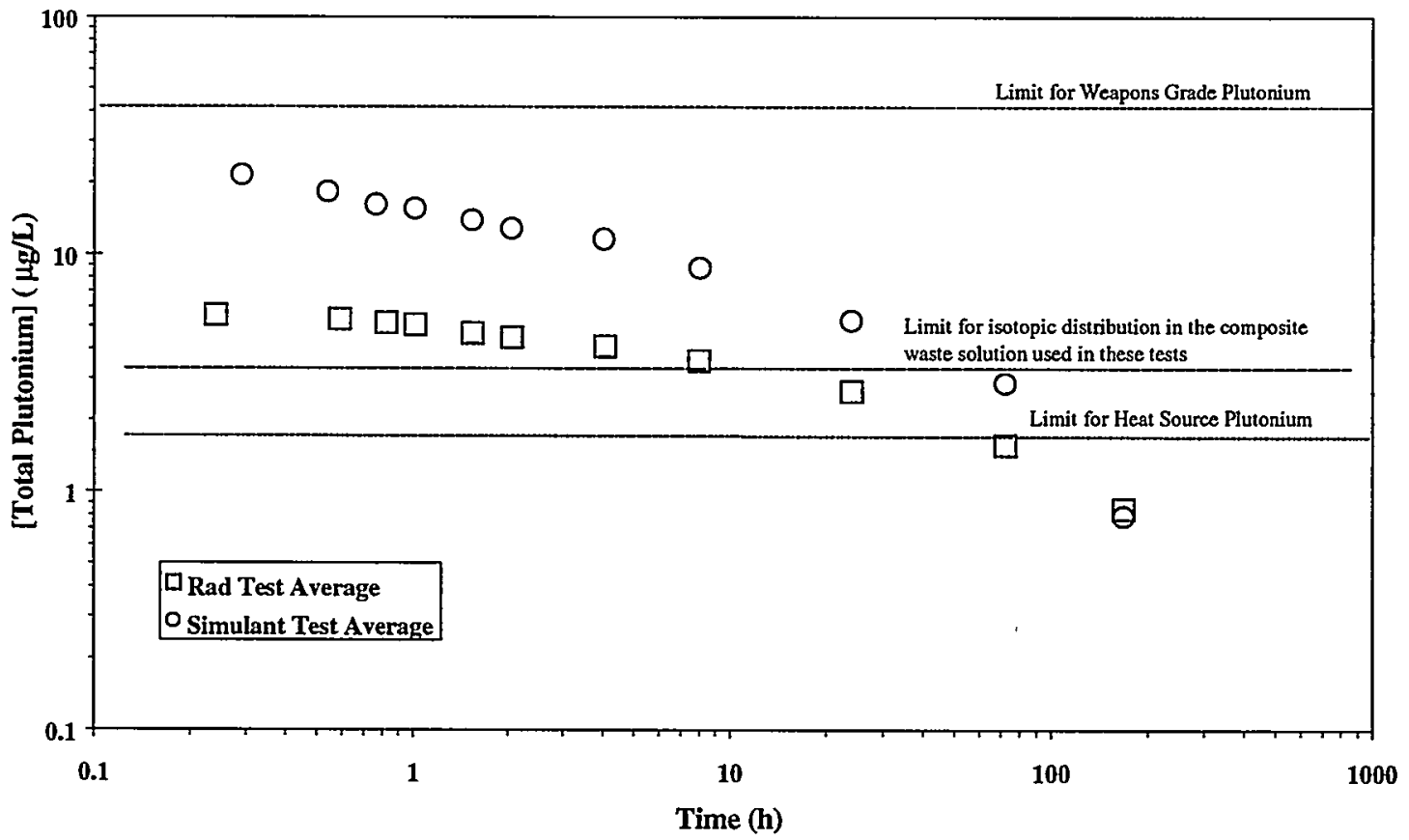




\section{Uranium Removal}

Figure 10 provides a graph of the average total uranium concentration versus time for both sodium concentrations. Table VIII presents the average and single standard deviation for the elapsed times, total uranium concentrations and decontamination factors measured at both ionic strength solutions. Appendices 2-7 contain experimental results for the individual tests.

Uranium removal occurred in the $7.5 \mathrm{M} \mathrm{Na}$ solution as evidenced by an average decontamination factor of $1.41 \pm 0.068$ (see Table VIII). Uranium removal proved lower in the $4.5 \mathrm{M} \mathrm{Na}$ solution with an average decontamination factor of $1.08 \pm 0.080$. The extent of uranium removal at the higher ionic strength $(7.5 \mathrm{M} \mathrm{Na})$ agrees with that previously measured with simulated waste solutions initially containing between 2560 and $24,600 \mu \mathrm{g} / \mathrm{L}$ uranium (see Table IX). The behavior of uranium in the $4.5 \mathrm{M}$ solution does not, however, agree with previous results obtained in Phases III and IV testing with simulated waste solutions $[4,5]$. For example, decontamination factors for uranium measured 1.24 in the Phase III tests initially containing $14,800 \mu \mathrm{g} / \mathrm{L}$ uranium and 1.31 in the Phase IV tests initially containing $9,020 \mu \mathrm{g} / \mathrm{L}$ uranium. The decontamination factor in the $4.5 \mathrm{M}$ Na radioactive waste tests average $1.08 \pm 0.08$, well below that measured in the above simulated waste solutions.

\section{Figure 10. Average Uranium Removal from Radioactive Waste Solutions} Diluted to $4.5 \mathrm{M}$ and $7.5 \mathrm{M}$ in Sodium

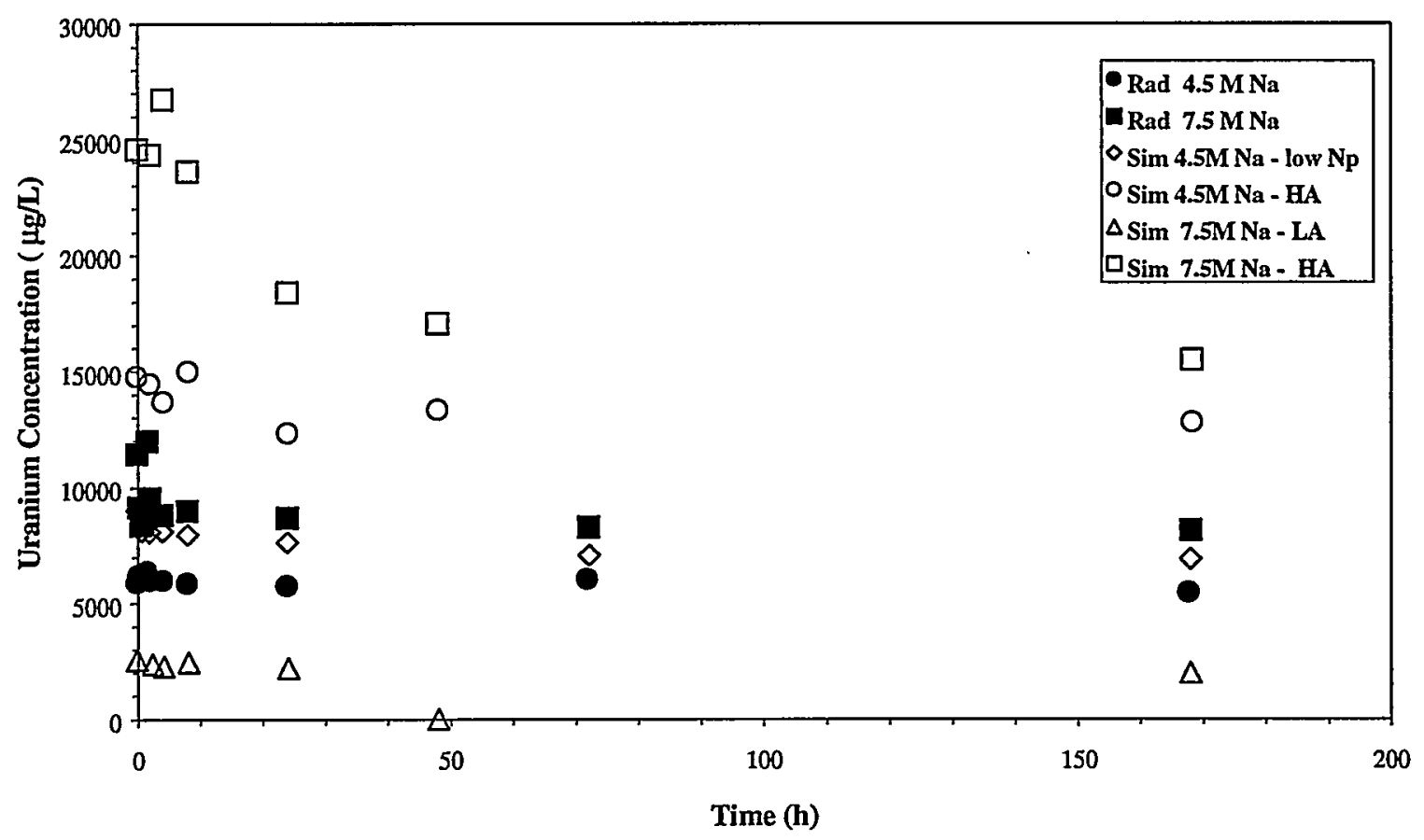




\section{Table VIII. Average Uranium Concentrations and Decontamination Factors} in Radioactive Waste Tests

\begin{tabular}{|c|c|c|c|c|c|}
\hline & & {$[\mathrm{Na}]=7.5 \mathrm{M}$} & & & \\
\hline Elapsed Time & Elapsed Time & [Total U] & [Total 0] & DF & DF \\
\hline $\begin{array}{c}\text { Average } \\
\text { (b) }\end{array}$ & $\begin{array}{l}\text { Std. Dev. } \\
\text { (b) }\end{array}$ & $\begin{array}{c}\text { Average } \\
(\mu g / L)\end{array}$ & $\begin{array}{c}\text { Std. Dev. } \\
(\mu \mathrm{g} / \mathrm{L})\end{array}$ & Average & Std. Dev. \\
\hline $0.00 \mathrm{E}+00$ & $0.00 \mathrm{E}+00$ & $1.15 E+04$ & $0.00 \mathrm{E}+00$ & $1.00 \mathrm{E}+00$ & $0.00 \mathrm{E}+00$ \\
\hline $2.42 \mathrm{E}-01$ & $1.18 \mathrm{E}-02$ & $9.14 \mathrm{E}+03$ & $6.16 \mathrm{E}+02$ & $1.26 \mathrm{E}+00$ & $8.49 \mathrm{E}-02$ \\
\hline $5.92 \mathrm{E}-01$ & $1.18 \mathrm{E}-02$ & $8.36 \mathrm{E}+03$ & $4.93 \mathrm{E}+02$ & $1.37 \mathrm{E}+00$ & $8.09 \mathrm{E}-02$ \\
\hline $8.25 \mathrm{E}-01$ & $1.18 \mathrm{E}-02$ & $8.67 \mathrm{E}+03$ & $3.88 \mathrm{E}+02$ & $1.32 \mathrm{E}+00$ & $5.92 \mathrm{E}-02$ \\
\hline $1.02 \mathrm{E}+00$ & $9.43 \mathrm{E}-02$ & $8.45 E+03$ & $9.35 E+01$ & $1.36 \mathrm{E}+00$ & $1.50 \mathrm{E}-02$ \\
\hline $1.53 E+00$ & $0.00 \mathrm{E}+00$ & $1.20 E+04$ & $2.22 E+03$ & $9.72 \mathrm{E}-01$ & $1.80 \mathrm{E}-01$ \\
\hline $2.04 \mathrm{E}+00$ & $5.89 \mathrm{E}-02$ & $9.56 \mathrm{E}+03$ & $4.01 \mathrm{E}+02$ & $1.20 \mathrm{E}+00$ & $5.04 \mathrm{E}-02$ \\
\hline $4.07 \mathrm{~T}+00$ & $4.71 \mathrm{E}-02$ & $8.83 E+03$ & $6.57 \mathrm{E}+02$ & $1.30 E+00$ & $9.69 \mathrm{E}-02$ \\
\hline $8.01 E+00$ & $1.18 \mathrm{E}-02$ & $8.99 \mathrm{E}+03$ & $5.54 \mathrm{E}+02$ & $1.28 \mathrm{E}+00$ & $7.88 \mathrm{E}-02$ \\
\hline $2.41 E+01$ & $2.36 \mathrm{E}-02$ & $8.69 \mathrm{E}+03$ & $4.50 \mathrm{E}+02$ & $1.32 E+00$ & $6.84 \mathrm{E}-02$ \\
\hline $7.21 E+01$ & $8.25 \mathrm{E}-02$ & $8.27 \mathrm{E}+03$ & $4.09 E+02$ & $1.39 \mathrm{E}+00$ & $6.88 \mathrm{E}-02$ \\
\hline $1.68 \mathrm{E}+02$ & $1.89 \mathrm{E}-01$ & $8.13 E+03$ & $3.90 \mathrm{E}+02$ & $1.41 E+00$ & $6.78 \mathrm{E}-02$ \\
\hline & & {$[\mathrm{Na}]=4.5 \mathrm{M}$} & & & \\
\hline Elapsed Time & Elapsed Time & [Total U] & [Total U] & $\mathbf{D F}$ & DF \\
\hline Average & Std. Dev. & Average & Std. Dev. & Average & Std. Dev. \\
\hline (h) & (h) & $(\mu g / L)$ & $(\mu g / L)$ & & \\
\hline $0.00 \mathrm{E}+00$ & $0.00 \mathrm{E}+00$ & $5.86 \mathrm{E}+03$ & $0.00 \mathrm{E}+00$ & $1.00 \mathrm{E}+00$ & $0.00 \mathrm{E}+00$ \\
\hline $3.00 \mathrm{E}-01$ & $7.07 \mathrm{E}-02$ & $6.20 \mathrm{E}+03$ & $4.28 \mathrm{E}+01$ & $9.45 \mathrm{E}-01$ & $6.52 \mathrm{E}-03$ \\
\hline $4.75 \mathrm{E}-01$ & $8.25 \mathrm{E}-02$ & $6.17 \mathrm{E}+03$ & $6.47 \mathrm{E}+01$ & $9.50 \mathrm{E}-01$ & $9.98 \mathrm{E}-03$ \\
\hline $8.67 \mathrm{E}-01$ & $2.36 \mathrm{E}-02$ & $6.05 \mathrm{E}+03$ & $1.96 \mathrm{E}+02$ & $9.70 \mathrm{E}-01$ & $3.14 \mathrm{E}-02$ \\
\hline $1.03 E+00$ & $1.18 \mathrm{E}-02$ & $6.00 \mathrm{E}+03$ & $3.86 \mathrm{E}+01$ & $9.77 \mathrm{E}-01$ & $6.29 \mathrm{E}-03$ \\
\hline $1.54 \mathrm{E}+00$ & $8.25 \mathrm{E}-02$ & $6.34 \mathrm{E}+03$ & $3.60 \mathrm{E}+02$ & $9.26 \mathrm{E}-01$ & $5.25 \mathrm{E}-02$ \\
\hline $2.02 E+00$ & $0.00 \mathrm{E}+00$ & $5.98 \mathrm{E}+03$ & $7.54 \mathrm{E}+01$ & $9.80 \mathrm{E}-01$ & $1.24 \mathrm{E}-02$ \\
\hline $4.04 \mathrm{E}+00$ & $1.06 \mathrm{E}-01$ & $5.96 \mathrm{E}+03$ & $3.71 \mathrm{E}+01$ & 9.83E-01 & 6.11E-03 \\
\hline $8.02 E+00$ & $1.18 \mathrm{E}-02$ & $5.85 \mathrm{E}+03$ & $1.37 \mathrm{E}+02$ & $1.00 \mathrm{E}+00$ & 2.35E-02 \\
\hline $2.40 \mathrm{E}+01$ & $3.54 \mathrm{E}-02$ & $5.74 \mathrm{E}+03$ & $2.73 E+02$ & $1.02 \mathrm{E}+00$ & $4.86 \mathrm{E}-02$ \\
\hline $7.20 \mathrm{E}+01$ & $9.43 \mathrm{E}-02$ & $6.04 \mathrm{E}+03$ & $6.14 E+02$ & $9.76 \mathrm{E}-01$ & $9.92 \mathrm{E}-02$ \\
\hline $1.68 \mathrm{E}+02$ & $4.71 \mathrm{E}-02$ & $5.44 E+03$ & $4.05 \mathrm{E}+02$ & $1.08 \mathrm{E}+00$ & $8.04 \mathrm{E}-02$ \\
\hline
\end{tabular}


Table IX. Uranium Decontamination Factors in Simulated and Radioactive Waste Solutions

Solution Matrix

Phase III - HAW

Phase III-LAW

Phase IV - Simulant

Phase IV - Rad Waste
Average Decontamination Factor

$\underline{7.5 \mathrm{M} \mathrm{Na}}$

1.63

1.35

nd

1.41
$4.5 \mathrm{M} \mathrm{Na}$

1.24

2.48

1.31

$$
\text { nd }=\text { not determined }
$$

Neptunium Removal

Figure 11 provides a graph of the average total neptunium concentration versus time for both sodium concentrations. Table $\mathrm{X}$ presents the average and single standard deviation for the elapsed times, total neptunium concentrations and decontamination factors measured at both ionic strength solutions. Appendices 2-7 contain experimental results for the individual tests.

Figure 11. Average Neptunium Removal from Radioactive Waste Solutions Diluted to $4.5 \mathrm{M}$ and 7.5M in Sodium

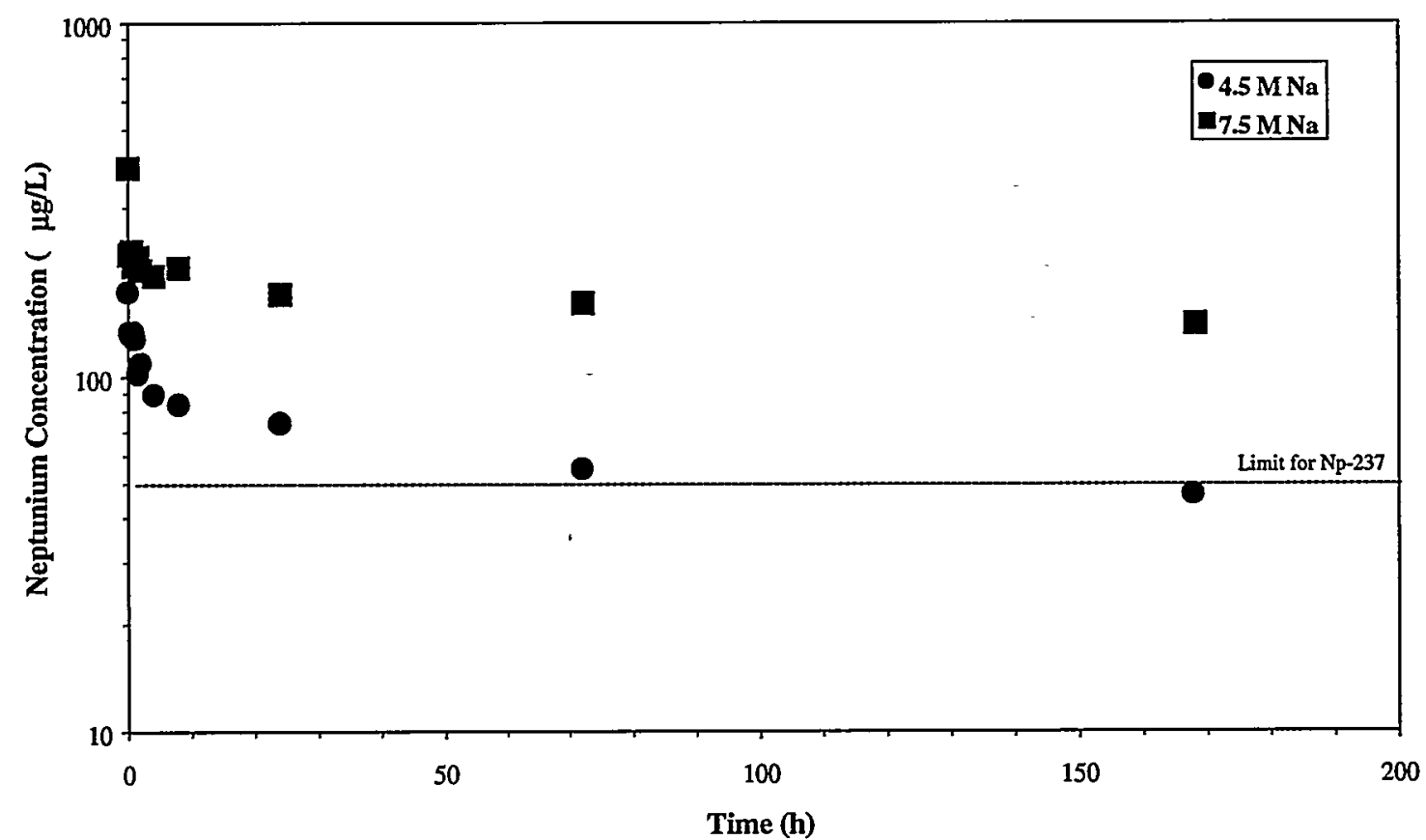

Neptunium removal achieved the Z-Area feed limit in the test at the $4.5 \mathrm{M} \mathrm{Na}$ concentration, but not at the 7.5M Na concentration. This result agrees with previous results with simulated waste solutions [4,5]. Inspection of Figures 11 and 12 indicates slow attainment of equilibrium $(\geq 168 \mathrm{~h})$. 
Table X. Average Neptunium Concentrations and Decontamination Factors in Radioactive Waste Tests

\begin{tabular}{|c|c|c|c|c|c|}
\hline \multirow[b]{2}{*}{ Elapsed Time } & \multicolumn{3}{|c|}{$[\mathrm{Na}]=7.5 \mathrm{M}$} & \multirow[b]{2}{*}{ DF } & \multirow[b]{2}{*}{ DF } \\
\hline & Elapsed Time & [Np-237] & {$[\mathrm{Np}-237]$} & & \\
\hline $\begin{array}{l}\text { Average } \\
\text { (h) }\end{array}$ & $\begin{array}{l}\text { Std. Dev. } \\
\text { (h) }\end{array}$ & $\begin{array}{c}\text { Average } \\
(\mu g / L)\end{array}$ & $\begin{array}{c}\text { Std. Dev. } \\
(\mu \mathrm{g} / \mathrm{L})\end{array}$ & Average & Std. Dev. \\
\hline $0.00 \mathrm{E}+00$ & $0.00 \mathrm{E}+00$ & $3.89 \mathrm{E}+02$ & $0.00 \mathrm{E}+00$ & $1.00 \mathrm{E}+00$ & $0.00 \mathrm{E}+00$ \\
\hline 2.42E-01 & $1.18 \mathrm{E}-02$ & $2.22 E+02$ & $3.12 E+01$ & $1.77 \mathrm{E}+00$ & $2.48 \mathrm{E}-01$ \\
\hline $5.92 \mathrm{E}-01$ & $1.18 \mathrm{E}-02$ & $2.27 \mathrm{E}+02$ & $1.60 \mathrm{E}+01$ & $1.72 \mathrm{E}+00$ & $1.21 \mathrm{E}-01$ \\
\hline $8.25 \mathrm{E}-01$ & $1.18 \mathrm{E}-02$ & $2.05 E+02$ & $1.52 \mathrm{E}+01$ & $1.90 \mathrm{E}+00$ & $1.41 \mathrm{E}-01$ \\
\hline $1.02 \mathrm{E}+00$ & $9.43 \mathrm{E}-02$ & $2.06 \mathrm{E}+02$ & $6.24 \mathrm{E}+00$ & $1.89 \mathrm{E}+00$ & 5.71E-02 \\
\hline $1.53 \mathrm{E}+00$ & $0.00 E+00$ & $2.18 \mathrm{E}+02$ & $5.12 E+01$ & $1.83 \mathrm{E}+00$ & $4.30 \mathrm{E}-01$ \\
\hline $2.04 \mathrm{E}+00$ & $5.89 \mathrm{E}-02$ & $2.00 \mathrm{E}+02$ & 7.07E-02 & $1.94 \mathrm{E}+00$ & $6.86 \mathrm{E}-04$ \\
\hline $4.07 \mathrm{E}+00$ & $4.71 \mathrm{E}-02$ & $1.93 E+02$ & $1.71 \mathrm{E}+01$ & $2.02 \mathrm{E}+00$ & $1.79 \mathrm{E}-01$ \\
\hline $8.01 \mathrm{E}+00$ & $1.18 \mathrm{E}-02$ & $2.04 \mathrm{E}+02$ & $1.87 \mathrm{E}+01$ & $1.92 \mathrm{E}+00$ & $1.76 \mathrm{E}-01$ \\
\hline $2.41 E+01$ & $2.36 \mathrm{E}-02$ & $1.71 E+02$ & $4.11 \mathrm{E}+01$ & $2.34 \mathrm{E}+00$ & $5.61 \mathrm{E}-01$ \\
\hline \multirow{3}{*}{$1.68 \mathrm{E}+02$} & $8.25 \mathrm{E}-02$ & $1.61 E+02$ & $3.01 \mathrm{E}+01$ & $2.45 \mathrm{E}+00$ & $4.58 \mathrm{E}-01$ \\
\hline & $1.89 \mathrm{E}-01$ & $1.41 \mathrm{E}+02$ & $2.57 \mathrm{E}+01$ & $2.81 E+00$ & $5.11 \mathrm{E}-01$ \\
\hline & \multicolumn{3}{|c|}{$[\mathrm{Na}]=4.5 \mathrm{M}$} & & \\
\hline Elapsed Time & Elapsed Time & [Np-237] & [Np-237] & $\mathbf{D F}$ & DF \\
\hline $\begin{array}{l}\text { Average } \\
\text { (h) }\end{array}$ & $\begin{array}{l}\text { Std. Dev. } \\
\text { (h) }\end{array}$ & $\begin{array}{c}\text { Average } \\
(\mu \mathrm{g} / \mathrm{L})\end{array}$ & $\begin{array}{c}\text { Std. Dev. } \\
(\mu \mathrm{g} / \mathrm{L})\end{array}$ & Average & Std. Dev. \\
\hline $0.00 \mathrm{E}+00$ & $0.00 E+00$ & $1.74 E+02$ & $0.00 \mathrm{E}+00$ & $1.00 \mathrm{E}+00$ & $0.00 \mathrm{E}+00$ \\
\hline $3.00 \mathrm{E}-01$ & 7.07E-02 & $1.34 \mathrm{E}+02$ & $1.12 \mathrm{E}+01$ & $1.30 \mathrm{E}+00$ & $1.09 \mathrm{E}-01$ \\
\hline $4.75 \mathrm{E}-01$ & $8.25 \mathrm{E}-02$ & $1.31 \mathrm{E}+02$ & $3.68 \mathrm{E}+00$ & $1.32 \mathrm{E}+00$ & $3.70 \mathrm{E}-02$ \\
\hline $8.67 \mathrm{E}-01$ & $2.36 \mathrm{E}-02$ & $1.34 \mathrm{E}+02$ & $1.61 \mathrm{E}+01$ & $1.31 \mathrm{E}+00$ & $1.58 \mathrm{E}-01$ \\
\hline $1.03 E+00$ & $1.18 \mathrm{E}-02$ & $1.28 \mathrm{E}+02$ & $2.64 \mathrm{E}+01$ & $1.39 E+00$ & $2.85 \mathrm{E}-01$ \\
\hline $1.54 \mathrm{E}+00$ & $8.25 \mathrm{E}-02$ & $1.02 E+02$ & $3.25 \mathrm{E}-01$ & $1.71 E+00$ & $5.45 \mathrm{E}-03$ \\
\hline $2.02 E+00$ & $0.00 E+00$ & $1.09 \mathrm{E}+02$ & $1.62 \mathrm{E}+01$ & $1.61 \mathrm{E}+00^{\circ}$ & 2.38E-01 \\
\hline $4.04 \mathrm{E}+00$ & $1.06 \mathrm{E}-01$ & $8.91 \mathrm{E}+01$ & $2.84 E+01$ & $2.05 E+00$ & $6.55 \mathrm{E}-01$ \\
\hline $8.02 E+00$ & $1.18 \mathrm{E}-02$ & $8.35 E+01$ & $6.31 \mathrm{E}+00$ & $2.09 \mathrm{E}+00$ & $1.57 \mathrm{E}-01$ \\
\hline $2.40 \mathrm{E}+01$ & $3.54 \mathrm{E}-02$ & $7.40 \mathrm{E}+01$ & $9.57 E+00$ & $2.37 \mathrm{E}+00$ & 3.07E-01 \\
\hline $7.20 \mathrm{E}+01$ & $9.43 \mathrm{E}-02$ & $5.49 \mathrm{E}+01$ & $1.63 \mathrm{E}+00$ & $3.17 \mathrm{E}+00$ & $9.38 \mathrm{E}-02$ \\
\hline $1.68 \mathrm{E}+02$ & $4.71 \mathrm{E}-02$ & $4.65 \mathrm{E}+01$ & $2.83 \mathrm{E}-02$ & $3.74 \mathrm{E}+00$ & $2.27 \mathrm{E}-03$ \\
\hline
\end{tabular}

Table XI provides the average decontamination factors for neptunium in simulated and radioactive waste solutions at a MST concentration of $0.2 \mathrm{~g} / \mathrm{L}$. The relative extent of neptunium removal increased slightly with a decrease in the sodium concentration in the waste solution (see Table XI). The decontamination factors measured for the radioactive waste solutions agree with those previously measured with simulated waste solutions. We attribute the lower DFs for the radioactive waste solutions compared to the Phase III 
LAW and Phase IV simulated waste solutions to higher uranium concentrations which compete for sites on the MST.

Table XI. Neptunium Decontamination Factors in Simulated and Radioactive Waste Solutions

\begin{tabular}{lcc} 
Solution Matrix & $7.5 \mathrm{M} \mathrm{Na}$ & $4.5 \mathrm{M} \mathrm{Na}$ \\
\hline Phase III - HAW & 1.72 & 1.49 \\
Phase III - LAW & 3.26 & 16.0 \\
Phase IV - Simulant & nd & 5.46 \\
Phase IV - Rad Waste & 2.81 & 3.74 \\
\multicolumn{2}{c}{ nd = not determined } &
\end{tabular}

Figure 12 presents the average neptunium concentration versus time data in the radioactive waste tests as well as that for previously reported simulated waste solutions $[4,5]$. The figure omits the initial neptunium concentrations to allow a log-log plot. In contrast to strontium and plutonium, the slopes of the concentration curves do not change abruptly at any point. Inspection of the graphs indicates that the rate of neptunium removal in the radioactive waste solutions appears very similar to that in the simulated waste solutions for both ionic strength conditions. Thus, we conclude that the neptunium removal rate data obtained from simulated waste solutions proves suitable for use in design calculations.

Figure 12. Comparison of Neptunium Removal in Radioactive Waste and Simulated Waste Solutions at 4.5M in Sodium

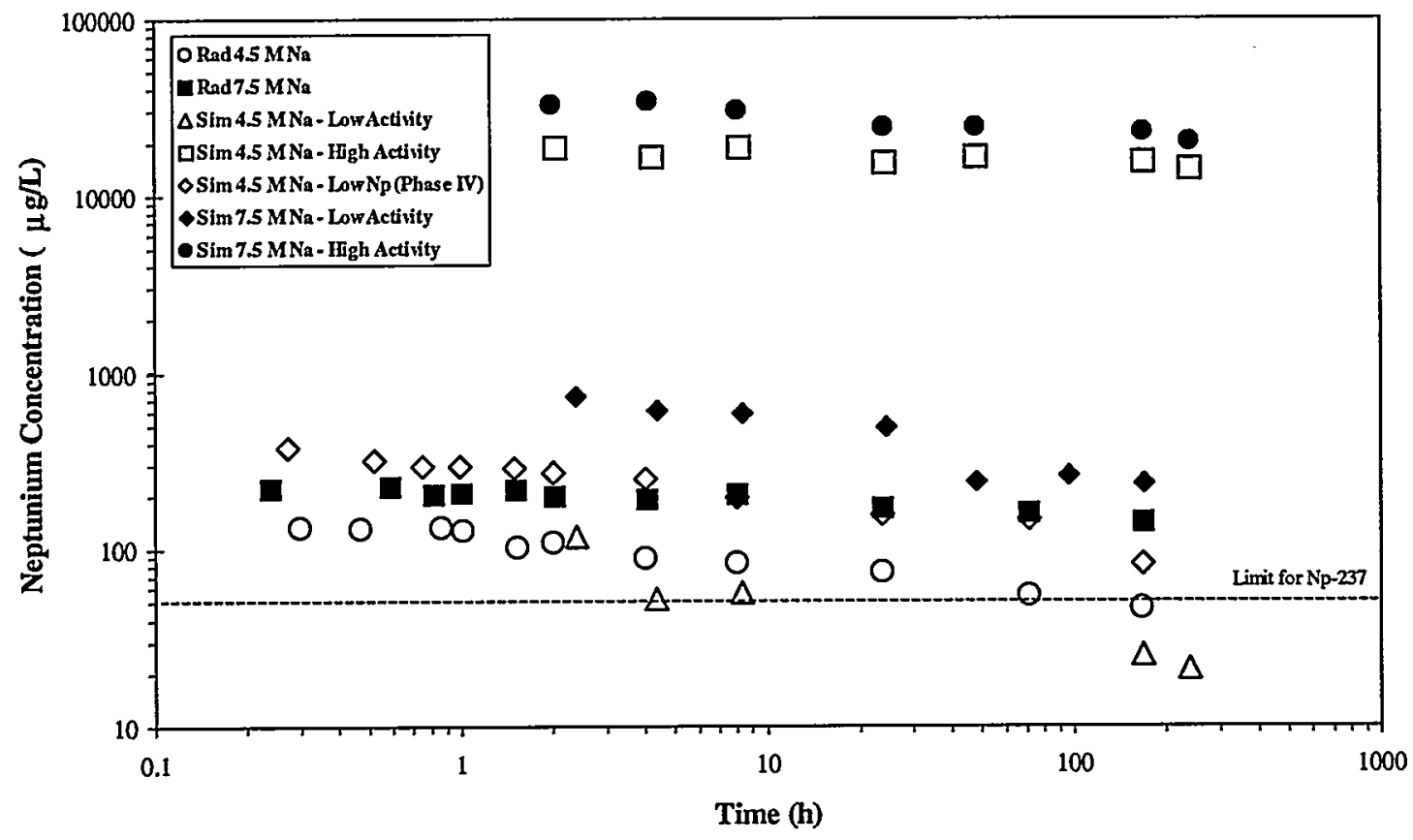




\section{Quality Assurance}

This work used the following task plan.

D. T. Hobbs "Task Technical and Quality Assurance Plan for Monosodium

Titanate Adsorption Kinetics Testing," WSRC-RP-99-00182, revision 0, February 5, 1999.

This document provides the final deliverable for the work requested in the authorizing task request,

J. R. Fowler, Technical Task Request, HLW-SDT-TTR-99-01.0, revision 0, January 21, 1999

Personnel recorded the experimental data from the radioactive waste testing in laboratory notebooks WSRC-NB-99-00062, WSRC-NB-99-00178 and WSRC-TR-99-00061.

\section{Acknowledgements}

The authors thank the many people who helped bring this work to completion. M.S. Blume and H. L. Thacker conducted much of the experimental work involved in the adsorption experiments. E. A. Kyser supplied actinide materials. The staff of the Analytical Developmental Section of the SRTC performed the many chemical and radiochemical analyses.

\section{References}

1. P. L. Rutland, "MST Alpha Removal and Hg Removal for Salt Team Phase 3 Evaluation," HLE-TAR-98062, Rev. 0, July 15, 1998.

2. D. T. Hobbs and D. D. Walker, "Plutonium and Uranium Adsorption on Monosodium Titanate (U)," WSRC-RP-92-93, August 13, 1992.

3. D. T. Hobbs and S. D. Fleischman, "Fissile Solubility and Monosodium Titanate Loading Tests (U)," WSRC-RP-92-1273, February 12, 1993.

4. D. T. Hobbs, M. G. Bronikowski, T. B. Edwards, and R. L. Pulmano, "Final Report on Phase III Testing of Monosodium Titanate Adsorption Kinetics," WSRC-TR-9900134 , Rev. 0, May 28, 1999.

5. D. T. Hobbs and R. L. Pulmano, "Phase IV Simulant Testing of Monosodium Titanate Adsorption Kinetics," WSRC-TR-99-00219, Rev. 0, June 29, 1999.

6. J. R. Fowler, Technical Task Request, HLW-SDT-TTR-99-01.0, Revision 0, January 21, 1999.

7. D. T. Hobbs "Task Technical and Quality Assurance Plan for Monosodium Titanate Adsorption Kinetics Testing," WSRC-RP-99-00182, Revision 0, February 5, 1999.

8. "WSRC 241-82H Control Room Process Requirements," WSRC-IM-91-63, Revision 20, October 1998.

9. D. T. Hobbs and D. G. Karraker, "Recent Results on the Solubility of Uranium and Plutonium in Savannah River Site Waste Supernate," Nuclear Technology, 114(1996), 318-324.

10. C. H. Delegard, "Solubility of $\mathrm{PuO}_{2} \mathrm{xH}_{2} \mathrm{O}$ in Alkaline Hanford High-Level Waste Solution," Radiochim. Acta, 41(1987) 11-21. 
Appendix 1.

Composition of Multi-Tank Composite Sample Prior to Treatment with NaTPB

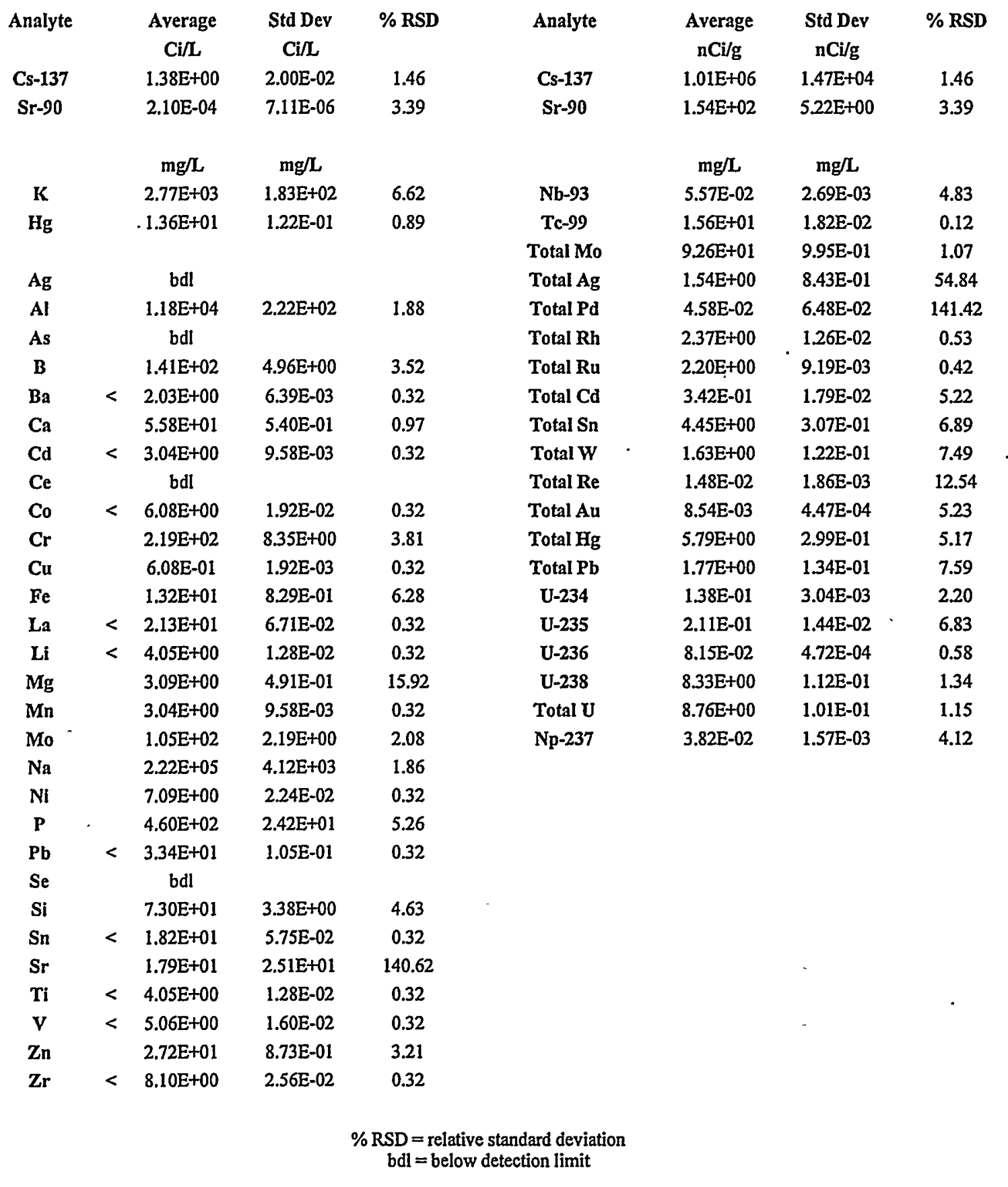


Appendix 2.

Concentration versus Time Data for Bottle 1

$\begin{array}{ccccc}\begin{array}{c}\text { Elapsed Time } \\ \text { (h) }\end{array} & \begin{array}{c}\text { [Total Sr] } \\ (\mu \mathrm{g} / \mathrm{L})\end{array} & \begin{array}{c}\text { [Total Pu] } \\ (\mu \mathrm{g} / \mathrm{L})\end{array} & \begin{array}{c}\text { [Np-237] } \\ (\mu \mathrm{g} / \mathrm{L})\end{array} & \begin{array}{c}\text { Total U] } \\ (\mu \mathrm{g} / \mathrm{L})\end{array} \\ 0.00 \mathrm{E}+00 & 4.00 \mathrm{E}+01 & 1.24 \mathrm{E}+01 & 3.13 \mathrm{E}+02 & 1.08 \mathrm{E}+04 \\ 3.50 \mathrm{E}-01 & 3.95 \mathrm{E}+01 & 1.16 \mathrm{E}+01 & 2.58 \mathrm{E}+02 & 1.05 \mathrm{E}+04 \\ 6.50 \mathrm{E}-01 & 3.92 \mathrm{E}+01 & 1.26 \mathrm{E}+01 & 3.35 \mathrm{E}+02 & 1.03 \mathrm{E}+04 \\ 7.83 \mathrm{E}-01 & 4.02 \mathrm{E}+01 & 1.41 \mathrm{E}+01 & 4.57 \mathrm{E}+02 & 1.10 \mathrm{E}+04 \\ 1.02 \mathrm{E}+00 & 4.02 \mathrm{E}+01 & 1.29 \mathrm{E}+01 & 3.66 \mathrm{E}+02 & 1.12 \mathrm{E}+04 \\ 1.50 \mathrm{E}+00 & 4.28 \mathrm{E}+01 & 1.37 \mathrm{E}+01 & 2.84 \mathrm{E}+02 & 1.06 \mathrm{E}+04 \\ 2.08 \mathrm{E}+00 & 4.50 \mathrm{E}+01 & 1.54 \mathrm{E}+01 & 4.60 \mathrm{E}+02 & 1.24 \mathrm{E}+04 \\ 4.00 \mathrm{E}+00 & 4.26 \mathrm{E}+01 & 1.41 \mathrm{E}+01 & 3.48 \mathrm{E}+02 & 1.19 \mathrm{E}+04 \\ 8.03 \mathrm{E}+00 & 4.33 \mathrm{E}+01 & 1.44 \mathrm{E}+01 & 5.82 \mathrm{E}+02 & 1.32 \mathrm{E}+04 \\ 2.41 \mathrm{E}+01 & 4.16 \mathrm{E}+01 & 1.34 \mathrm{E}+01 & 4.27 \mathrm{E}+02 & 1.18 \mathrm{E}+04 \\ 7.21 \mathrm{E}+01 & 3.99 \mathrm{E}+01 & 1.35 \mathrm{E}+01 & 4.94 \mathrm{E}+02 & 1.21 \mathrm{E}+04 \\ 1.68 \mathrm{E}+02 & 3.81 \mathrm{E}+01 & 1.38 \mathrm{E}+01 & 3.48 \mathrm{E}+02 & 1.17 \mathrm{E}+04 \\ & & & & \\ \text { Average } & 4.10 \mathrm{E}+01 & 1.35 \mathrm{E}+01 & 3.89 \mathrm{E}+02 & 1.15 \mathrm{E}+04 \\ \text { Std. Dev. } & 2.03 \mathrm{E}+00 & 1.02 \mathrm{E}+00 & 9.55 \mathrm{E}+01 & 8.76 \mathrm{E}+02 \\ \% \text { RSD } & 4.94 \% & 7.55 \% & 24.54 \% & 7.64 \%\end{array}$

Appendix 3.

Concentration versus Time Data for Bottle 2 7.5M [Na], 0.2 g/L MST

$\begin{array}{ccccc}\begin{array}{c}\text { Elapsed Time } \\ (\mathbf{h})\end{array} & \begin{array}{c}{[\text { Total Sr] }} \\ (\mu \mathrm{g} / \mathrm{L})\end{array} & \begin{array}{c}\text { [Total Pu] } \\ (\mu \mathrm{g} / \mathrm{L})\end{array} & \begin{array}{c}\text { [Np-237] } \\ (\mu \mathrm{g} / \mathrm{L})\end{array} & \begin{array}{c}\text { [Total U] } \\ (\mu \mathrm{g} / \mathrm{L})\end{array} \\ 0.00 \mathrm{E}+00 & 4.00 \mathrm{E}+01 & 1.35 \mathrm{E}+01 & 3.89 \mathrm{E}+02 & 1.15 \mathrm{E}+04 \\ 2.50 \mathrm{E}-01 & 9.93 \mathrm{E}+00 & 9.54 \mathrm{E}+00 & 2.45 \mathrm{E}+02 & 9.57 \mathrm{E}+03 \\ 6.00 \mathrm{E}-01 & 4.87 \mathrm{E}+00 & 1.06 \mathrm{E}+01 & 2.38 \mathrm{E}+02 & 8.71 \mathrm{E}+03 \\ 8.17 \mathrm{E}-01 & 4.57 \mathrm{E}+00 & 1.23 \mathrm{E}+01 & 2.16 \mathrm{E}+02 & 8.94 \mathrm{E}+03 \\ 1.08 \mathrm{E}+00 & 3.59 \mathrm{E}+00 & 1.06 \mathrm{E}+01 & 2.02 \mathrm{E}+02 & 8.38 \mathrm{E}+03 \\ 1.53 \mathrm{E}+00 & 3.18 \mathrm{E}+00 & 1.07 \mathrm{E}+01 & 1.82 \mathrm{E}+02 & 1.04 \mathrm{E}+04 \\ 2.00 \mathrm{E}+00 & 3.20 \mathrm{E}+00 & 1.18 \mathrm{E}+01 & 2.00 \mathrm{E}+02 & 9.85 \mathrm{E}+03 \\ 4.10 \mathrm{E}+00 & 2.14 \mathrm{E}+00 & 1.05 \mathrm{E}+01 & 1.81 \mathrm{E}+02 & 9.29 \mathrm{E}+03 \\ 8.00 \mathrm{E}+00 & 1.98 \mathrm{E}+00 & 1.11 \mathrm{E}+01 & 1.90 \mathrm{E}+02 & 9.38 \mathrm{E}+03 \\ 2.40 \mathrm{E}+01 & 1.68 \mathrm{E}+00 & 9.48 \mathrm{E}+00 & 2.00 \mathrm{E}+02 & 9.01 \mathrm{E}+03 \\ 7.22 \mathrm{E}+01 & 1.58 \mathrm{E}+00 & 8.14 \mathrm{E}+00 & 1.83 \mathrm{E}+02 & 8.56 \mathrm{E}+03 \\ 1.68 \mathrm{E}+02 & 1.62 \mathrm{E}+00 & 6.22 \mathrm{E}+00 & 1.59 \mathrm{E}+02 & 8.40 \mathrm{E}+03\end{array}$


Appendix 4.

Concentration versus Time Data for Bottle 3

7.5M [Na], 0.2 g/L MST

$\begin{array}{ccccc}\begin{array}{c}\text { Elapsed Time } \\ (\mathbf{h})\end{array} & \begin{array}{c}{[\text { Total Sr] }} \\ (\mu \mathrm{g} / \mathrm{L})\end{array} & \begin{array}{c}\text { [Total Pu] } \\ (\mu \mathrm{g} / \mathrm{L})\end{array} & \begin{array}{c}\text { [Np-237] } \\ (\mu \mathrm{g} / \mathrm{L})\end{array} & \begin{array}{c}\text { [Total U] } \\ (\mu \mathrm{g} / \mathbf{L})\end{array} \\ 0.00 \mathrm{E}+00 & 4.00 \mathrm{E}+01 & 1.35 \mathrm{E}+01 & 3.89 \mathrm{E}+02 & 1.15 \mathrm{E}+04 \\ 2.33 \mathrm{E}-01 & 1.39 \mathrm{E}+01 & 1.03 \mathrm{E}+01 & 2.00 \mathrm{E}+02 & 8.70 \mathrm{E}+03 \\ 5.83 \mathrm{E}-01 & 8.11 \mathrm{E}+00 & 1.09 \mathrm{E}+01 & 2.16 \mathrm{E}+02 & 8.02 \mathrm{E}+03 \\ 8.33 \mathrm{E}-01 & 6.85 \mathrm{E}+00 & 1.22 \mathrm{E}+01 & 1.94 \mathrm{E}+02 & 8.40 \mathrm{E}+03 \\ 9.50 \mathrm{E}-01 & 6.36 \mathrm{E}+00 & 1.18 \mathrm{E}+01 & 2.11 \mathrm{E}+02 & 8.51 \mathrm{E}+03 \\ 1.53 \mathrm{E}+00 & 5.33 \mathrm{E}+00 & 1.13 \mathrm{E}+01 & 2.55 \mathrm{E}+02 & 1.36 \mathrm{E}+04 \\ 2.08 \mathrm{E}+00 & 4.74 \mathrm{E}+00 & 1.26 \mathrm{E}+01 & 2.00 \mathrm{E}+02 & 9.28 \mathrm{E}+03 \\ 4.03 \mathrm{E}+00 & 3.26 \mathrm{E}+00 & 1.08 \mathrm{E}+01 & 2.05 \mathrm{E}+02 & 8.37 \mathrm{E}+03 \\ 8.02 \mathrm{E}+00 & 2.66 \mathrm{E}+00 & 1.08 \mathrm{E}+01 & 2.17 \mathrm{E}+02 & 8.60 \mathrm{E}+03 \\ 2.41 \mathrm{E}+01 & 1.98 \mathrm{E}+00 & 9.12 \mathrm{E}+00 & 1.42 \mathrm{E}+02 & 8.37 \mathrm{E}+03 \\ 7.20 \mathrm{E}+01 & 1.74 \mathrm{E}+00 & 7.98 \mathrm{E}+00 & 1.40 \mathrm{E}+02 & 7.98 \mathrm{E}+03 \\ 1.68 \mathrm{E}+02 & 1.57 \mathrm{E}+00 & 6.06 \mathrm{E}+00 & 1.23 \mathrm{E}+02 & 7.85 \mathrm{E}+03\end{array}$

Appendix 5.

\section{Concentration versus Time Data for Bottle 4}

4.5M [Na], no MST

$\begin{array}{ccccc}\begin{array}{c}\text { Elapsed Time } \\ \text { (h) }\end{array} & \begin{array}{c}\text { TTotal Sr] } \\ (\mu \mathrm{g} / \mathrm{L})\end{array} & \begin{array}{c}\text { [Total Pu] } \\ (\mu \mathrm{g} / \mathrm{L})\end{array} & \begin{array}{c}\text { [Np-237] } \\ (\mu \mathrm{g} / \mathrm{L})\end{array} & \begin{array}{c}\text { [Total U] } \\ (\mu \mathrm{g} / \mathrm{L})\end{array} \\ 0.00 \mathrm{E}+00 & 2.42 \mathrm{E}+01 & 8.43 \mathrm{E}+00 & 1.40 \mathrm{E}+02 & 5.73 \mathrm{E}+03 \\ 4.00 \mathrm{E}-01 & 2.35 \mathrm{E}+01 & 7.95 \mathrm{E}+00 & 1.72 \mathrm{E}+02 & 5.47 \mathrm{E}+03 \\ 5.33 \mathrm{E}-01 & 2.56 \mathrm{E}+01 & 8.09 \mathrm{E}+00 & 1.75 \mathrm{E}+02 & 5.73 \mathrm{E}+03 \\ 8.50 \mathrm{E}-01 & 2.42 \mathrm{E}+01 & 8.06 \mathrm{E}+00 & 1.92 \mathrm{E}+02 & 5.71 \mathrm{E}+03 \\ 1.13 \mathrm{E}+00 & 2.57 \mathrm{E}+01 & 8.33 \mathrm{E}+00 & 1.52 \mathrm{E}+02 & 5.74 \mathrm{E}+03 \\ 1.52 \mathrm{E}+00 & 2.44 \mathrm{E}+01 & 8.35 \mathrm{E}+00 & 2.00 \mathrm{E}+02 & 6.52 \mathrm{E}+03 \\ 2.07 \mathrm{E}+00 & 2.47 \mathrm{E}+01 & 8.33 \mathrm{E}+00 & 1.75 \mathrm{E}+02 & 5.86 \mathrm{E}+03 \\ 4.03 \mathrm{E}+00 & 2.52 \mathrm{E}+01 & 8.35 \mathrm{E}+00 & 1.61 \mathrm{E}+02 & 5.83 \mathrm{E}+03 \\ 7.98 \mathrm{E}+00 & 2.53 \mathrm{E}+01 & 8.33 \mathrm{E}+00 & 2.11 \mathrm{E}+02 & 5.83 \mathrm{E}+03 \\ 2.41 \mathrm{E}+01 & 2.48 \mathrm{E}+01 & 8.12 \mathrm{E}+00 & 1.38 \mathrm{E}+02 & 5.64 \mathrm{E}+03 \\ 7.20 \mathrm{E}+01 & 2.44 \mathrm{E}+01 & 7.78 \mathrm{E}+00 & 1.79 \mathrm{E}+02 & 6.49 \mathrm{E}+03 \\ 1.68 \mathrm{E}+02 & 2.34 \mathrm{E}+01 & 8.52 \mathrm{E}+00 & 1.89 \mathrm{E}+02 & 5.75 \mathrm{E}+03 \\ & & & & \\ \text { Average } & 2.46 \mathrm{E}+01 & 8.22 \mathrm{E}+00 & 1.74 \mathrm{E}+02 & 5.86 \mathrm{E}+03 \\ \text { Std. Dev. } & 7.40 \mathrm{E}-01 & 2.20 \mathrm{E}-01 & 2.27 \mathrm{E}+01 & 3.19 \mathrm{E}+02 \\ \% \text { RSD } & 3.01 \% & 2.67 \% & 13.09 \% & 5.45 \%\end{array}$


Appendix 6.

Concentration versus Time Data for Bottle 5

4.5M [Na], 0.2 g/L MST

$\begin{array}{ccccc}\begin{array}{c}\text { Elapsed Time } \\ \text { (h) }\end{array} & \begin{array}{c}\text { [Total Sr] } \\ (\mu \mathrm{g} / \mathrm{L})\end{array} & \begin{array}{c}\text { [Total Pu] } \\ (\mu \mathrm{g} / \mathrm{L})\end{array} & \begin{array}{c}{[\mathrm{Np}-237]} \\ (\mu \mathrm{g} / \mathrm{L})\end{array} & \begin{array}{c}\text { [Total U] } \\ (\mu \mathrm{g} / \mathbf{L})\end{array} \\ 0.00 \mathrm{E}+00 & 2.42 \mathrm{E}+01 & 8.22 \mathrm{E}+00 & 1.74 \mathrm{E}+02 & 5.86 \mathrm{E}+03 \\ 3.50 \mathrm{E}-01 & 2.01 \mathrm{E}+00 & 5.98 \mathrm{E}+00 & 1.42 \mathrm{E}+02 & 6.17 \mathrm{E}+03 \\ 5.33 \mathrm{E}-01 & 1.54 \mathrm{E}+00 & 5.61 \mathrm{E}+00 & 1.34 \mathrm{E}+02 & 6.21 \mathrm{E}+03 \\ 8.83 \mathrm{E}-01 & 1.26 \mathrm{E}+00 & 5.27 \mathrm{E}+00 & 1.45 \mathrm{E}+02 & 5.91 \mathrm{E}+03 \\ 1.03 \mathrm{E}+00 & 1.09 \mathrm{E}+00 & 5.26 \mathrm{E}+00 & 1.47 \mathrm{E}+02 & 6.03 \mathrm{E}+03 \\ 1.60 \mathrm{E}+00 & 8.83 \mathrm{E}-01 & 4.70 \mathrm{E}+00 & 1.02 \mathrm{E}+02 & 6.08 \mathrm{E}+03 \\ 2.02 \mathrm{E}+00 & 7.87 \mathrm{E}-01 & 4.61 \mathrm{E}+00 & 1.21 \mathrm{E}+02 & 6.03 \mathrm{E}+03 \\ 4.12 \mathrm{E}+00 & 5.91 \mathrm{E}-01 & 4.16 \mathrm{E}+00 & 1.09 \mathrm{E}+02 & 5.99 \mathrm{E}+03 \\ 8.03 \mathrm{E}+00 & 4.51 \mathrm{E}-01 & 3.56 \mathrm{E}+00 & 8.80 \mathrm{E}+01 & 5.75 \mathrm{E}+03 \\ 2.40 \mathrm{E}+01 & 3.67 \mathrm{E}-01 & 2.60 \mathrm{E}+00 & 6.72 \mathrm{E}+01 & 5.55 \mathrm{E}+03 \\ 7.21 \mathrm{E}+01 & 2.95 \mathrm{E}-01 & 1.54 \mathrm{E}+00 & 5.37 \mathrm{E}+01 & 5.60 \mathrm{E}+03 \\ 1.68 \mathrm{E}+02 & 2.70 \mathrm{E}-01 & 8.18 \mathrm{E}-01 & 4.65 \mathrm{E}+01 & 5.15 \mathrm{E}+03\end{array}$

Appendix 7.

Concentration versus Time Data for Bottle 6 4.5M [Na], 0.2 g/LMST

$\begin{array}{ccccc}\begin{array}{c}\text { Elapsed Time } \\ (\mathbf{h})\end{array} & \begin{array}{c}\text { [Total Sr] } \\ (\mu \mathrm{g} / \mathrm{L})\end{array} & \begin{array}{c}\text { Total Pu] } \\ (\mu \mathrm{g} / \mathrm{L})\end{array} & \begin{array}{c}\text { [Np-237] } \\ (\mu \mathrm{g} / \mathrm{L})\end{array} & \begin{array}{c}\text { [Total U] } \\ (\mu \mathrm{g} / \mathrm{L})\end{array} \\ 0.00 \mathrm{E}+00 & 2.42 \mathrm{E}+01 & 8.22 \mathrm{E}+00 & 1.74 \mathrm{E}+02 & 5.86 \mathrm{E}+03 \\ 2.50 \mathrm{E}-01 & 1.41 \mathrm{E}+00 & 5.12 \mathrm{E}+00 & 1.26 \mathrm{E}+02 & 6.23 \mathrm{E}+03 \\ 4.17 \mathrm{E}-01 & 1.01 \mathrm{E}+00 & 5.09 \mathrm{E}+00 & 1.29 \mathrm{E}+02 & 6.12 \mathrm{E}+03 \\ 8.50 \mathrm{E}-01 & 7.33 \mathrm{E}-01 & 4.99 \mathrm{E}+00 & 1.22 \mathrm{E}+02 & 6.18 \mathrm{E}+03 \\ 1.02 \mathrm{E}+00 & 7.01 \mathrm{E}-01 & 4.89 \mathrm{E}+00 & 1.09 \mathrm{E}+02 & 5.97 \mathrm{E}+03 \\ 1.48 \mathrm{E}+00 & 5.97 \mathrm{E}-01 & 4.62 \mathrm{E}+00 & 1.02 \mathrm{E}+02 & 6.59 \mathrm{E}+03 \\ 2.02 \mathrm{E}+00 & 5.54 \mathrm{E}-01 & 4.38 \mathrm{E}+00 & 9.78 \mathrm{E}+01 & 5.92 \mathrm{E}+03 \\ 3.97 \mathrm{E}+00 & 4.26 \mathrm{E}-01 & 4.04 \mathrm{E}+00 & 6.90 \mathrm{E}+01 & 5.93 \mathrm{E}+03 \\ 8.02 \mathrm{E}+00 & 3.67 \mathrm{E}-01 & 3.59 \mathrm{E}+00 & 7.91 \mathrm{E}+01 & 5.95 \mathrm{E}+03 \\ 2.39 \mathrm{E}+01 & 3.19 \mathrm{E}-01 & 2.69 \mathrm{E}+00 & 8.07 \mathrm{E}+01 & 5.94 \mathrm{E}+03 \\ 7.19 \mathrm{E}+01 & 3.27 \mathrm{E}-01 & 1.62 \mathrm{E}+00 & 5.60 \mathrm{E}+01 & 6.47 \mathrm{E}+03 \\ 1.68 \mathrm{E}+02 & 3.14 \mathrm{E}-01 & 8.80 \mathrm{E}-01 & 4.65 \mathrm{E}+01 & 5.73 \mathrm{E}+03\end{array}$




\section{DISTRIBUTION}

\section{J. L. Barnes, 704-3N}

M. J. Barnes, 773-A

S. B. Beck, 704-19S

T. E. Britt, 703-H

M. G. Bronikowski, 773-A

J. T. Carter, 704-3N

W. C. Clark, 704-56H

T. B. Edwards, 773-42A

H. H. Elder, 704-190N

S. D. Fink, 773-A

F. F. Fondeur, 773-A

J. R. Fowler, 704-196N

D. C. Hannah, 703-46A

D. T. Hobbs, 773-A

E. W. Holtzscheiter, 773-A

P. R Jackson, 703-46A

R. A. Jacobs, 704-196N

R. T. Jones, 704-3N

L. F. Landon, 704-T

B. L. Lewis, 703-H

T. J. Lex, 703-H

P. E. Lowe, 773-41A

D. J. McCabe, 773-42A

J. W. McCollough, 704-3N

J. P. Morin, 703-H

L. M. Nelson, 773-43A

L. M. Papouchado, 773-A

S. F. Piccolo, 704-3N

R. A. Peterson, 773-41A

S. F. Peterson, 773-41A

J. A. Pike, 704-3N

K. J. Rueter, 704-3N

P. L. Rutland, 704-196N

M. G. Schwenker, 703-46A

R. H. Spires, 703-H

W. E. Stevens, 773-A

P. C. Suggs, 704-19爪N

G. A. Taylor, $704-19 \circlearrowleft \mathrm{N}$

W. L. Tamosaitis, 773-A

W. B. Van Pelt, 773-43A

D. D. Walker, 773-A

W. R. Wilmarth, 773-42A

G. T. Wright, 773-A

TIM, 703-43A

LWP Files c/o C. C. Canada, 773-A

ITP Files c/o C. J. Smalls, 241-147H 